\title{
İşsizlik Sorununa Fenomenolojik Bir Yaklaşım: Üniversite Mezunu Genç İşsizlerin Görüşlerine Göre İsssizlik Sorunu
}

\section{A Phenomenological Approach to the Unemployment Problem: From the Views of Young Unemployed Undergraduates}

\begin{abstract}
Aydın ÇívíLid $\breve{G}^{*}$
Öz: $\mathrm{Bu}$ araştırmada işsizlik olgusu, üniversite mezunu işsiz insanların görüşleri doğrultusunda incelenmeye çalışılmıştır. Katılımcılar sözlü rızaları alınarak çalışmaya dahil edilmiştir. Katılımcılardan 9'u Kadın, (\%56.25), 7'si Erkektir (\% 43.75) ve yaş ortalamaları 27.75'dir. Çalışmada araştırmacı tarafından oluşturulan yarı yapılandırılmış görüşme formu kullanılmıştır. Elde edilen yanıtlar nitel yöntemle incelenmiş, verilere içerik analizi uygulanmıştır. Sonuçlara göre; katılımcıların iş yaşamının insanlar için önemi temasına verdikleri yanıtlar; psikolojik güç, varoluş gereksinimi, para kazanmak ve amaçlı yaşam olmak üzere dört kategori altında incelenmiştir. İşsizliğin neden olduğu ekonomik sorunlar teması doğrultusunda; yaşamsal gereksinimleri karşlayamamak, aileye yük olmak ve ekonomik bağl1lık ile geçim sıkıntısı yaşamak şeklinde üç kategori oluşturularak analiz yapılmıştır. İşsizliğin neden olduğu sosyal sorunlar teması doğrultusunda, sosyal faaliyetlere katılamamak, toplumsal baskı, arkadaşlardan uzaklaşmak, evlenememek ve boşanmak şeklinde dört kategori oluşturulmuştur. İşsizliğin neden olduğu psikolojik sorunlar temasına yönelik yanıtlarda ise en fazla $\% 25$ oranıyla üzüntü olduğu belirlenmiştir. İşsizlik için çözüm önerileri teması doğrultusunda, katılımcıların yanıtlarından eğitim stratejisi oluşturulması, işe alımlarda adil tutum ve istihdam politikası oluşturulması yönünde üç kategori oluşturularak analiz edilmiştir. Elde edilen sonuçlar literatüre göre tartışılmıştır.
\end{abstract}

Anahtar sözcükler: İşsizlik, Genç İşsiz, Üniversite Mezunu, Fenomenoloji, Nitel Analiz

\begin{abstract}
In this study, the phenomenon of unemployment has been tried to be examined in accordance with the opinions of unemployed undergraduated people. Participants were included in the study by obtaining their verbal consent. The research was done with semi structured interview form by researcher. Nine of the participants were female (56.25\%), 7 were male (43.75\%) and the mean age was 27.75. In the study, the responses obtained from the participants were examined by qualitative method and content analysis was applied to the data. According to results; participants' responses to the theme of the importance of business life for people; Psychological power, necessity of existence, earning money and purposeful life were examined under four categories. In line with the theme of economic problems caused by unemployment; the analysis was conducted by creating three categories: not being able to meet the vital requirements, being a burden on the family and experiencing economic dependence and subsistence. Four categories were formed from participants' responses to the theme of social problems caused by unemployment, not being able to participate in social activities, social pressure, getting away from friends, not getting married and getting divorced. In the responses received from the participants for the theme of psychological problems caused by unemployment, it was found that sadness was at most $25 \%$. In line with the theme of solution proposals for unemployment, three categories were formulated and analyzed in order to form a training strategy, fair attitude in recruitment and employment policy. The results were discussed in the light of literature.
\end{abstract}

Keywords: Unemployment, Young Unemployed, Undergraduate, Phenomenology, Qualitative Analysis * Doç. Dr., Akdeniz Üniversitesi, Edebiyat Fakültesi, Psikoloji Bölümü, Antalya. aydinc@akdeniz.edu.tr,
https://orcid.org/0000-0002-6142-0928 
İnsan hayatında iş yaşamı önemli bir rol oynamaktadır. İnsanlar aldıkları eğitim sonrası diplomaları, yetenekleri ve donanımlarına göre iş yaşamına atılarak hayatlarını ve geçimlerini kazanmayı hedeflemektedir. Coğrafi, etnik veya kültürel farklılık olmaksızın insanlar temel eğitim sonrası ilgi ve becerilerinin olduğu bir alanda bilgi, deneyim ve gelişimlerini sürdürmek için mesleki eğitim veya üst öğrenim kurumlarına giderek nitelikli iş veya meslek sahibi olma çabası içindedir. Günümüzde eğitim, iş ya da meslek sahibi olabilmek için önemli bir gerekliliktir. Bu nedenle insanlar, iş yaşamında kendilerini başarıya götürecek iyi ve kaliteli eğitim koşulları arayışı içindedir. Bu arayışın amacı kişinin aldığı eğitim, ilgi, istek ve yetenekleri doğrultusunda bir iş yapmak istemesidir. İnsanları çalışmaya iten nedir? Ya da insanlar neden iş aramaktadır? Sorularına yalnızca insanın gereksinimlerini karşılamak istemesi şeklinde genel bir cevap vermek gerçekçi olmaz. İnsanların çalışma nedeni kişisel amaç, üretken olmak, kültür, sosyal yaşam gibi farklı unsurlardan etkilenmektedir. Sosyalleşme ihtiyacı, toplumsal yapıda bir iş ve meslek sahibi olarak statü kazanmak, kariyerle ilgili planlar yapmak, yaşam standardını yükseltmek, bakmakla yükümlü olduğu insanların geçimini sağlamak, toplum yararını gözetmek, zamanı üretken kullanmak gibi farklı nedenlerle insanın çalıştığı söylenebilir. Ancak tüm bunların dışında insanların çalışmasındaki öncelikli neden yaşamını sürdürebileceği bir gelire sahip olmaktır (Çivilidağ 2018, 54).

Günümüzde insanlar için iş yaşamı beklentinin ötesinde bir zorunluluk haline gelmiştir. İş̧ ve emek karşılığı iş görenin para kazanması yaşamsal gereksinimlerini karşılamasının yanında hayatını ve geleceğini planlamasına olanak sağlamaktadır. İşs sahibi olmak aynı zamanda toplumsal yapının çekirdeğini oluşturan aile kurumunu oluşturmak ve geçim için de gereklidir. Ancak birey iş yaşamına atılmak için tüm koşullara sahip olduğu halde kendisine uygun bir iş bulamıyorsa bu durumda bireyin işsizlik sorunu ile karşı karşıya olduğu söylenebilir. İşsizlik, kişinin çalışma isteğine, gücüne ve yeteneğine sahip olup, cari ücret ile çalışma saatlerini kabul etmesine rağmen iş bulamama ve işe yerleşememe durumudur. Bir diğer ifadeyle işsizlik, bireyin ihtiyaçlarını karşılayan ekonomik kaynakların kısmen veya tamamen ortadan kalktığı; kişinin, ailenin ve toplumun doğrudan olumsuz olarak etkilendiği bir süreçtir (Sandalcılar 2012, 225). İşsizlik homojen bir olgu olmayıp, işsizliğin açık, iradi, istem dışı, yapısal, teknolojik, mevsimsel işsizlik gibi çeşitli türleri vardır. Açık işsizlik, çalışmaya hazır olduğu halde aradığ işi bulamayanların yaşadığ 1 işsizliktir. İradi işsizlik, kişinin aradığ 1 işi bulduğu fakat çalışma koşulları ve ücreti uygun bulmadığ piyasasında mevcut koşullara göre çalışmaya razı olduğu halde bireyin iş bulamadığı işsizliktir. Yapısal işsizlik, ekonominin yapısal özelliklerinden veya hızlı ekonomik değişimlerden (ekonomik kriz, resesyon gibi) kaynaklanan işsizliktir. Teknolojik işsizlik, iş piyasasında insan gücü veya emeği yerine makine, robot, yapay zeka gibi teknolojinin kullanılmasına bağlı ortaya çıkan işsizliktir. Mevsimsel işsizlik, mevsim koşullarına bağlı ortaya çıkan işsizliktir. Türkiye'de mevsimsel işsizlik tarım, balıkçılık, turizm gibi sektörlerde daha çok görülmektedir (Sümer et al. 2013, 24).

İşsizlik özellikle gelişmemiş ve gelişmekte olan ülkelerdeki insanların gündemlerinde yer alan en önemli sorunlardan biridir. Fakat Amerika Birleşik Devletleri, Kanada, Almanya, İngiltere ve Japonya gibi gelişmiş ülkelerde 2017-2019 yılları arasında işsizlik istikrarlı olarak düşme eğilimindedir. Küresel düzeyde işsizlik 2009 'da $\% 5.6$ oranında iken 2018 'de $\% 5$ oranına gerilemiştir (ILO 2019). Türkiye'de ise 2008 yılından sonra işsizlik oranı sürekli artma eğilimindedir. 15 ve daha üst yaşlardaki işsiz sayısı 2019 y1lı Mart ayında \%14.1 artarak 4 milyon 544 bin kişi, genç nüfusta (15-24 yaş) işsizlik oranı \%25.2 ve 15-64 yaş grubunda bu oran \%14.3 olarak gerçekleşmiştir (TÜİK 2019). Özellikle genç işsizlik, Türkiye gibi gelişmekte olan ülkeler için önlem alınması gereken, bireyi etkilediği gibi birey dışında tüm toplumu da etkileyen hayati bir sorundur. İşsizliğin bireyler üzerindeki tipik psikolojik ve sosyal etkileri, düşük özsaygı, topluma ve kurumlara yabancılaşmada artış, evliliklerde anlaşmazlık ve gergin- 
lik, depresyon, anksiyete, endişe, iş bulamamaktan dolayı derin utanç, stres, psikosomatik ve fiziksel hastalıklar olarak açıklanabilir (Stack \& Haas 1984, 18). İşsizliğin en yıkıcı etkisi hem birey hem de toplum düzeyinde sosyal bağlar üzerinde parçalanmaya yol açan alkol, uyuşturucu ve intihar gibi ölümcül riskleri ortaya çıkarmasıdır. İşsizlik hem erkekler hem de kadınlar için intihar riski barındırmaktadır. İşsizlik, psikososyal rahatsızlıklar olarak bilinen durumları dikkate almayı gerektirdiği gibi intihar düşüncesi ve davranışıyla da ilişkilidir. Bu nedenle işsizlik intihar için doğrudan bir risk faktörüdür (Preti 2003, 557).

İşsizlik ile ilgili araştırmalarda öne çıkan teorilerden Jahoda'nın (1982) yoksunluk teorisinde (deprivation of theory) işin örtük fonksiyonlarına vurgu yapılmıştır. Teoride gelir kaybı daha az önemsenirken işin örtük işlevleri; zamanı yapılandırma, sosyal etkileşim, amaçlar, hedefler, kişisel statü ve düzenli aktivite olarak açıklanmıştır. İşsizlik durumunda insanlar tipik bir şekilde bu psikolojik işlevlerden yoksun kalacaktır. Jahoda'nın kuramsal yaklaşımının önemli zaafiyetinden biri işsizliğin eşlik ettiği gelir kaybını ihmal etmesidir. Fakat işsizliği yalnızca gelir kaybı olarak görmekte kısıtlı bir bakış açısına sahip olmaktır. İşsizlik çoğu zaman evliliklerin bozulmasına eşten sağlanan sosyal desteğin kaybolmasına da yol açmaktadır (Halvorsen 1998, 229).

İşsizlikle ilgili Avustralya'da yapılan iki çalışma işsizliğin finansal ve finansal olmayan yönlerini ortaya koymuştur. Flatau, Gaalea ve Petridis (2000) akıl sağlığı ve işsizlik arasındaki ilişkide tutarlı ve güçlü bir ilişki bulurken, gelirin daha az etkiye sahip olduğunu belirlemiştir. Diğer çalışmada Creed ve Macintyre (2001) işsiz bireylerde finansal sorun psikolojik sağlığın en önemli yordayıcısıdır. Ancak bunun yanı sıra işsizlik zamanı yapılandırma veya planlama, aktivite, statü, ortak amaç ve sosyal etkileşim gibi insan yaşamındaki önemli unsurları baltalayan bir etkiye de sahiptir (Akt. Ganley 2002, 183). İşsizlik hem erkeklerde hem de kadınlarda olumsuz fiziksel, duygusal ve sağlıkla ilgili sonuçlar ortaya koymaktadır. İşsiz kadınlar ve erkeklerin yaş, maddi durum ve eğitim durumu kontrol edildiğinde bu insanların çalışanlara göre daha fazla acı çektikleri ve şikayetlerinin daha uzun sürdügü belirlenmiştir. İşsiz insanlar, uyku bozukluğu, depresyon, anksiyete bozukluğu, madde bağımlılığı ve intihar nedeniyle sağlık merkezlerini daha sık kullanmaktadır (Kroll \& Lampert 2009, 47). İşsizlik birçok insanın psikolojik sağlığını olumsuz olarak etkilese de insanlar işsizliğe aynı şekilde tepki vermeyebilir. Ancak işsiz bireylerde psikolojik sağlıkla ilişkili olarak dikkate alınması gereken önemli faktörlerden biri işsiz bireylerin ne kadar süre işsiz kaldığıdır. Uzayan işsizlik süresi insanları daha stresli hale getirmekte, ekonomik durumlarının düzeleceğine yönelik umutlarını kaybetmelerine neden olmaktadır (Bilgiç \& Y1lmaz 2013, 1001).

Son yıllarda Türkiye'de işsizlik toplumsal sorunların en üst sıralarında ve sıklıkla gündemde yer alan önemli bir sorun haline gelmiştir. İşsizliğin ekonomik parametrelerle, üretimle ve eğitimle yakından ilişkili olduğu düşünülünce uygulanan ekonomi ve eğitim politikalarının işsizlik sorununu etkilediği gözlenmektedir. Dolayısıyla Türkiye'de işsizlik en fazla genç eğitimli bireyleri olumsuz olarak etkilemektedir. Bu nedenle bu araştırmanın amacı, işsizlik sorununu işsiz üniversite mezunu katılımcıların görüşlerine göre nitel analizin fenomenolojik yöntemine göre incelemektir. İşsizlik sorunu gelişmemiş ve gelişmekte olan ülkeler için toplumsal sorunlardan biri olsa da bu sorunu yaşayan bireyin işsizlik sorununa yönelik algısı, içsel yaşantılarının anlaşılması ve soruna yönelik değerlendirmeleri de önemlidir. Bu doğrultuda bireylerin işsizlik sorununa yönelik öznel algı ve yaşantılarının anlaşılması ve incelenmesi için araştırmada fenomenolojik yöntem kullanılmıştır. Bunun için iş yaşamının insan için önemi, işsizliğin katılımcılarda ne tür yaşantılara yol açtı̆̆ ların neler olduğu, işsiz bireylerin kimlerden, ne tür sosyal destek algıladığı ve işsizliğe katılımcıların nasıl çözüm önerileri getirdiği bu araştırma kapsamında anlaşılmaya çalışılmıştır.

$\mathrm{Bu}$ doğrultuda araştırmada cevabı aranan sorular şunlardır: 
1. İşsiz bireylere göre iş yaşamının insanlar için önemi nedir?

2. İşsiz bireylere göre işsizlik ne gibi ekonomik sorunlara yol açmaktadır?

3. İşsiz bireylere göre işsizlik ne gibi sosyal sorunlara yol açmaktadır?

4. İşsiz bireylere göre işsizlik ne gibi psikolojik sorunlara yol açmaktadır?

5. İşsiz bireylerin işsizliğin sonuçlarına ilişkin görüşleri nedir?

6. İșsiz bireylerin işsizliğin çözümüne yönelik görüşleri nedir?

7. İşsiz bireylerin işsizlik sürecinde algıladıkları sosyal destek kaynakları ve türleri nedir?

\section{Yöntem}

$\mathrm{Bu}$ araştırma sosyal bilimlerde bir kişi, olgu, durum veya olayın derinlemesine incelenmesini gerektiren durumlarda kullanılan nitel araştırma yöntemiyle yapılmıştır. Araştırmada ele alınan işsizlik konusu nitel araştırma desenlerinden olgu bilim (fenomenoloji) kapsamına uygundur. Olgu bilim, ... "yaşantıları ve anlamları çıkarmaya yöneliktir. Bu amaçla yapılan içerik analizinde verinin kavramsallaştırılması ve olguyu tanımlayabilecek temaların ortaya çıkarılması çabası vardır. Sonuçlar betimsel anlatım ile sunulur ve sık sık doğrudan alıntılara yer verilir. Bunun yanında ortaya çıkan temalar ve örüntüler çerçevesinde elde edilen bulgular açıklanır ve yorumlanır. Olgu bilim araştırmalarında başlıca veri toplama aracı görüşmedir" (Yıldırım \& Şimşek 2013, 81).

\section{İşlem}

$\mathrm{Bu}$ araştırmada veriler, Antalya'da aktif olarak iş arayan üniversite mezunu bireylerle yapılan görüşmelerden elde edilmiştir. Araştırmacı tarafından hazırlanan yarı yapılandırılmış görüşme formu, sosyal bilimlerde nitel araştırma yöntemiyle araştırma yapmış olan iki araştırmacının görüşü doğrultusunda oluşturulmuştur. Bunun için araştırmacı tarafından alan yazın dikkate alınarak hazırlanan soruların uygunluğunun değerlendirilmesi amacıyla üç işsiz üniversite mezunu bireyle ayrı ayrı ön görüşmeler yapılmış, yapılan görüşmeler katılımcıların sözlü rızası ile ses kaydına alınmıştır. Alınan yanıtların araştırma amacına uygunluğu uzman görüşüne göre değerlendirilmiştir. Uzmanların önerisi doğrultusunda bazı görüşme soruları çıkarılmış, bazı sorular da yeniden düzenlenerek görüşme formuna son hali verilmiştir. Asıl araştırma 10 Şubat 10 Mayıs 2019 tarihleri arasında gönüllü 18 kişinin katılımı ile yapılmış, veri analizi katılımcılardan ikisinin yüzeysel, kısa ve araştırma sorularına ilgisiz yanıtlar vermesi nedeniyle 16 katılımcının yanıtları üzerinden gerçekleştirilmiştir. 16 katılımcı ile yapılan görüşmelerin toplam süresi, 203 dakika 18 saniyedir, ortalama görüşme süresi ise 13 dakika 24 saniyedir. Görüşmeler araştırmacı tarafindan Antalya il merkezindeki bir İş KUR'un önünde yapılmıştır. Görüşülen ortam görüşme yapmak ve ses kaydı almak için uygun bir yer olarak belirlenmiştir ve görüşmeler yüz yüze yapılmıştır. Katılımcılara araştırma hakkında kısa bilgi verildikten sonra araştırmaya katılımları için sözlü onamları alınmıştır. Cinsiyet, yaş, medeni durum, mezun oldukları üniversite, işsizlik maaşı alıp almadıkları gibi bilgiler sorulduktan sonra görüşme sorularına geçilmiştir. "İssizlik hakkında ne düşünüyorsunuz?" Sorusu ısınma amaçlı yöneltilen ilk sorudur. Bu sorudan sonra yöneltilen "İs yaşamının insanlar için önemi sizce nedir? Açıklar misınız?" Araştırmanın ilk sorusudur. "Size göre Türkiye'deki işsiz üniversite mezunu genç insanlar ne gibi ekonomik sorunlar yaşamaktadır? Açılar mısınız?" Araştırmanın ikinci sorusudur. Üçüncü soru, "Size göre Türkiye'deki işsiz üniversite mezunu genç insanlar ne gibi sosyal sorunlar yaşamaktadır? Açılklar mısınız?” Dördüncü soru, "Size göre Türkiye'deki işsiz üniversite mezunu genç insanlar ne gibi psikolojik sorunlar yaşamaktadır? Açıklar mısınız?" Beşinci soru, "İ̧ssizliğin neden olduğu sonuçlar nedir? Açıklar misınız?" Altıncı soru "Size göre Türkiye'deki işsiz üniversite mezunu genç insanların yaşadığ işsizlik sorunu için çözüm önerileri nedir? Neler yapılabilir açıklar mısınız?" Son soru olarak "işsizlik süresi içinde kim ya da kimlerden ne tür sosyal destek aldınız, açıklar mısınız?” Araştırmada işsizliğe yönelik metafor 
sorusu da yöneltilmiş ancak uzman görüşleri dikkate alınarak yanıtlar analize alınmamıştır.

\section{Katılımcilar}

Araştırma işsiz bireyler üzerinde yapıldığı için amaçlı örnekleme yönteminin tipik örnekleme türü kullanılmıştır. Tipik örnekleme, "sıradan bir insanı, durumu ya da araştırılan olgu örneğini yansıtmak için seçilir” (Merriam 2013, 77). Katılımcıların kimliklerinin deşifre olmaması için A1 ile D4 arasında kodlama yapılmıştır.

Tablo 1. Katılımcılara ait demografik bilgiler

\begin{tabular}{|c|c|c|c|c|c|c|}
\hline Katılımeı & Cinsiyet & Yaş & $\begin{array}{l}\text { Medeni } \\
\text { Durum }\end{array}$ & Mezun Olunan Alan & $\begin{array}{l}\text { İşsizlik } \\
\text { Süresi }\end{array}$ & $\begin{array}{l}\text { İşsizlik Maaşı } \\
\text { Alınıyor mu? }\end{array}$ \\
\hline A1 & Kadın & 24 & Bekar & İşletme-Pazarlama & $1 \mathrm{Y}_{11}$ & Hayır \\
\hline A2 & Erkek & 31 & Boşanmış & Hukuk & $2 Y_{11}$ & Hayır \\
\hline A3 & Kadın & 25 & Bekar & Beslenme ve Diyetetik & $1 Y_{1}$ & Hayır \\
\hline A4 & Erkek & 36 & Evli & Makine Mühendisliği & 5 Ay & Hayır \\
\hline B1 & Erkek & 26 & Bekar & Enerji Mühendisliği & 5 Ay & Hayır \\
\hline B2 & Kadın & 25 & Bekar & Matematik & $2 Y_{11}$ & Hayır \\
\hline B3 & Kadın & 30 & Evli & Veteriner & $7 \mathrm{Y} 1 \mathrm{l}$ & Hayır \\
\hline B4 & Kadın & 24 & Bekar & Gastronomi & $1 Y_{11}$ & Hayır \\
\hline C1 & Kadın & 24 & Bekar & Okul Öncesi Öğretmenliği & $1,5 Y_{11}$ & Hayır \\
\hline $\mathrm{C} 2$ & Erkek & 21 & Bekar & Turizm İşletmeciliği & $2 Y_{11}$ & Hayır \\
\hline $\mathrm{C} 3$ & Kadın & 24 & Bekar & Gazetecilik & $1 Y_{11}$ & Hayır \\
\hline $\mathrm{C} 4$ & Kadın & 28 & Bekar & Türk Dili ve Edebiyatı & $2 Y_{11}$ & Hayır \\
\hline D1 & Erkek & 27 & Bekar & Gıda Mühendisliği & $1 Y_{11}$ & Hayır \\
\hline D2 & Erkek & 31 & Bekar & $\begin{array}{lll}\text { Girişimcilik } & \text { ve } & \text { Yenilik } \\
\text { Yönetimi } & & \end{array}$ & 2 Ay & Hayır \\
\hline D3 & Erkek & 42 & Boşanmış & İşletme & $1,5 \mathrm{Y} 1 \mathrm{l}$ & Hayır \\
\hline D4 & Kadın & 26 & Bekar & T1bbi Sekreterlik & 6 Ay & Hayır \\
\hline
\end{tabular}

Tablo 1'den anlaşılacağı üzere, katılımcıların 9'u kadın (\%56.25) ve 7'si erkektir (\%43.75). 12 katılımcının medeni durumu bekar (\%75), 2 katılımcı evli (\%12.5) ve 2 katılımcı da boşanmıştır (\%12.5). Katılımcılar genel olarak farklı yükseköğretim programlarından mezundur. 3 Katılımcı mühendislik alanının farklı alt disiplininden (\%18.7) mezunken, 2 katılımcı (\%12.5) işletme mezunudur. Katılımcıların işsiz kaldığı süre 5 Ay ile 7 yıl arasında değişmektedir ve hiçbir katılımcı işsizlik maaşı almadığını belirtmiştir.

\section{Veri Analizi}

Katılımcılardan araştırma konusu ile ilgili elde edilen sesli yanttlar üç psikoloji öğrencisi tarafından dinlenerek yazıya aktarılmış (transkripti yapılmış) daha sonra araştırmacı tarafından metin üzerinde kodlamalar yapılmış ve temalar altında kategoriler oluşturulmuştur. Araştırmacı tarafından sesli kayıtlar ile transkriptler arasındaki uyum her bir görüşme tek tek dinlenerek kontrol edilmiştir. Araştırmacı transkriptler üzerinde veri kodlama ve tema oluşturma çalışmaları yapmıştır. Araştırmacı güvenilir ve geçerli çalışma sonucuna ulaşabilmek için oluşturduğu kodlar ve temaların ve tema adlandırmalarının uygunluğu ile ilgili iki sosyal bilimcinin görüşlerinden yararlanmıştır. Öneriler doğrultusunda kodlar ve temalar gözden geçirilerek analize uygun hale getirilmiştir. Araştırmacı tarafından veriler üzerinde kodlama yapılmış olup, belirlenen temalarla ilişkili kodlar araştırmacı tarafından kategoriler altında toplanmıştır. Kategoriler adlandırılırken kodları tanımlayacak ve kapsayacak şemsiye kavram oluşturulmuş ve iki uzmanın görüşleri de alınarak kategoriler üzerinde son kavramlaştırma yapılmıştır.

Katılımcıların iş yaşamının insanlar için önemi temasına verdikleri yanıtlar doğrultusunda dört kategori oluşturulmuştur. Bunlardan ilki, psikolojik güçtür. Psikolojik güç kategorisi, iş yaşamının günümüz insanı için özgürlük, özgüven, uyum sağlama, düzenli hayat ve rahat düşünme kodlarından oluşturulmuştur. Psikolojik güç, iş yaşamının insanlarda dengeli, sağlıklı ve 
uyumlu bir psikolojik yapının gelişimine işaret etmektedir. İkincisi varoluş gereksinimidir. Varoluş gereksinimi, Yaşamak için gereklilik, hayatı devam ettirmek ve ihtiyaçları karşılayabilme kodlarından oluşturulmuştur. Varoluş gereksinimi, insanların yaşamlarını sürdürebilmek için temel bir ihtiyaçtır. Üçüncü kategori para kazanmaktır. Para insanların yaşamlarını devam ettirebilmek, gereksinimlerini karşılayabilmek için bir araçtır. İnsanlar iş ve emek karş1lığ ettikleri para ile günlük, haftalık, aylık veya y1llık her türden gereksinimlerini ve geçimlerini sağlayabilirler. Para kategorisi, gelir kaynağ 1 , geçim kaynağı ve maddiyat kodlarından oluşturulmuştur. Para, şehirlerde yaşayan günümüz insanının hayatını idame ettirmesinde vazgeçilmez öneme sahiptir. Dördüncü kategori amaçlı yaşamdır. Amaçlı yaşam, insanın geleceğe yönelik amaçlar ve hedefler belirlemesi için önemlidir. İnsan geleceği planlayarak yaşar, bunun için de iş yaşamı insana maddi ve manevi kazanç sağlayarak geleceği planlamasına olanak tanır. Amaç11 yaşam, hedef belirleme, başarma duygusu, gelişim ve değişim kodlarından oluşturulmuştur.

Katılımcıların işsizliğin neden olduğu ekonomik sorunlar temasına verdikleri yanıtlar doğrultusunda; üç kategori oluşturulmuştur. Bunlardan birincisi yaşamsal gereksinimleri karşılayamamak kategorisidir. Bireylerin gıda, giyim, ulaşım, su, elektrik, doğalgaz, internet gibi zorunlu ihtiyaçlarını içermektedir. Ekonomik sorunlara yönelik katılımcıların verdiği yanıtlardan oluşturulan ikinci kategori aileye yük olmak ve ekonomik bağl1lıktır. İşsiz bireyler ebeveynleriyle yaşamak zorunda kaldıkları için gereksinimlerini ailelerinin maddi desteğiyle karşılamak durumundadır. Dolayısıyla işsiz bireyler, kazanç sağlayacak bir işe sahip olmadıkları için ailelerine yük olduklarını ve ihtiyaçlarını ailelerinin maddi desteğiyle karşılamak durumunda kaldıkları için kendilerini ebeveynlerine bağlı hissetmektedir. Ekonomik sorunlara yönelik katılımcıların verdiği yanıtlardan oluşturulan üçüncü kategori geçim sıkıntısı yaşamaktır. İnsanlar sahip oldukları gelirleriyle giderlerini denkleştiremediklerinde geçinemediklerini ifade ederler.

İşsizliğin neden olduğu sosyal sorunlar temasına yönelik katılımcıların yanıtlarından dört kategori oluşturulmuştur. Birincisi sosyal faaliyetlere (konser, sinema, tiyatro, doğum günü etkinlikleri vb.) katılamamaktır. Sosyal faaliyetlerin para harcamayı gerektirmesi nedeniyle işsiz bireyler bu tür etkinliklerden uzaklaşmaktadır. İkincisi toplumsal baskı, işsiz bireyler insanlarla günlük iletişimlerinde ne iş yaptıkları sorusu ile karşılaştıklarında kendilerini baskı altında hissedebilmektedir. Üçüncüsü arkadaşlardan uzaklaşmaktır. İnsanlar arkadaşlarıyla sosyal etkileşimde bulunduklarında para harcama ile karşı karşıya kalabilirler, işsizler de bu durumdan kaçınmak için arkadaşlarından uzaklaşmayı tercih etmektedir. Dördüncüsü evlenememe veya boşanmak kategorisi adında oluşturulmuştur. Evlenmek için düzenli bir iş ve gelir olması gereklidir işsiz insanlar buna sahip olmadıkları için ya evlenmeyi ertelemekte veya evlenmek istememektedir. Evli insanlar işsizlik durumunda ailelerinin geçimini ve gereksinimini karşılayamadıkları için ekonomik ve sosyal sorunlar nedeniyle boşanma durumunda kalabilmektedir.

İşsizliğin sonuçları temasına yönelik alınan yanıtlar doğrultusunda iki kategori oluşturulmuştur. İlki bireysel sonuçlar kategorisidir, bu kategorinin kodları mutsuz hayat, düşük maaş ile çalışmak zorunda olmak, psikolojik sorunlar, hayat kuramamak, evlenememek gibi bireysel düzeyde öne çıkan problemler iken, ikincisi toplumsal sonuçlardır. Bu kategori için oluşturulan kodlar; beyin göçü, ülke kalkınmasının olumsuz etkilenmesi, boşanma, ahlaki ve sosyal sorunları kapsamaktadır.

Katılımcıların işsizlik için çözüm önerileri temasına verdikleri yanıtlar doğrultusunda; üç kategori oluşturulmuştur. Bunlardan birincisi eğitim stratejisi oluşturulmasıdır. Bu kategoride katılımcılar ağıllıklı olarak iki görüş üzerinde durmuştur. Bunlardan birincisi yükseköğretim kademesindeki programlardan istihdam olanağı sınırlı olanların ya öğrenci alımını durdurması ya da kapatılması gerektiği, ikincisi eğitim süreci içinde mesleki yönlendirmenin yapılmasıdır. İkinci kategori işe alımlarda adil tutum adında oluşturulmuştur. Bu kategorinin kapsamı, işe alımlarda torpil, adam kayırmacılığın yapılmaması, liyakatin dikkate alınmasıdır. Ayrıca işe 
alımlarda mülakatın kaldırılması ve yeni mezunlardan iş tecrübesinin aranmamasıdır. Üçüncü kategori ise istihdam politikası oluşturulmasıdır. Bu kategorinin kapsamı da yeni iş alanları açılması, devletin özel sektörü teşvik etmesi ve kurumların daha fazla işgören alımı yapmasıdır.

Temaların sistemli ve daha anlaşılır olması için tablolar eşliğinde sunulması benimsenmiştir. Araştırmanın nitel yöntemle yapılmasına karşılık tablolarda (n, f, \% gibi) nicel verilere de yer verilmiş̧tir.

\section{Bulgular}

Verilere uygulanan içerik analizi ile araştırmanın temaları altında oluşturulan kategoriler doğrultusunda katılımcılardan elde edilen bulgulara aşağıda yer verilmiştir.

Tablo 2. İş yaşamının insanlar için önemi temasına göre oluşturulan kategoriler

\begin{tabular}{|c|c|c|c|c|c|c|c|c|c|c|c|c|c|c|c|c|c|c|c|}
\hline & \multicolumn{19}{|c|}{ Katılımcilar } \\
\hline & & $\mathrm{A}$ & A & $\mathrm{A}$ & A & B & $\mathrm{B}$ & B & B & $\mathrm{C}$ & $\mathrm{C}$ & $\mathrm{C}$ & $\mathrm{C}$ & $\mathrm{D}$ & $\mathrm{D}$ & $\mathrm{D}$ & $\mathrm{D}$ & & \\
\hline & Kategoriler & 1 & 2 & 3 & 4 & 1 & 2 & 3 & 4 & 1 & 2 & 3 & 4 & 1 & 2 & 3 & 4 & $\mathrm{f}$ & $\%$ \\
\hline 1 & Psikolojik Güç & $\sqrt{ }$ & $\sqrt{ }$ & $\sqrt{ }$ & $\sqrt{ }$ & & $\sqrt{ }$ & $\sqrt{ }$ & & & $\sqrt{ }$ & $\sqrt{ }$ & $\sqrt{ }$ & & & & $\sqrt{ }$ & 10 & 62.5 \\
\hline 2 & Varoluş Gereksinimi & & & $\sqrt{ }$ & & & & & $\sqrt{ }$ & $\sqrt{ }$ & & $\sqrt{ }$ & $\sqrt{ }$ & $\sqrt{ }$ & $\sqrt{ }$ & $\sqrt{ }$ & & 8 & 50.0 \\
\hline 3 & Para kazanmak & $\sqrt{ }$ & & & & $\sqrt{ }$ & & & & $\sqrt{ }$ & & $\sqrt{ }$ & $\sqrt{ }$ & & $\sqrt{ }$ & $\sqrt{ }$ & & 7 & 43.7 \\
\hline 4 & Amaçlı Yaşam & & & & $\sqrt{ }$ & & & & & & & & & & $\sqrt{ }$ & & & 2 & 12.5 \\
\hline
\end{tabular}

Tablo 2'de görüldüğü gibi, iş yaşamının insanlar için önemi temasıyla ilgili olarak katılımcılardan 10'nu (\%62.5) yanıtlarında psikolojik güç, 8'i (\%50) varoluş gereksinimini, 7'si (\%43.7) para kazanmak ve 2'si (\%12.5) amaçlı yaşam yönünde açıklama yapmıştır. Psikolojik güç kategorisine ilişkin bazı katılımcıların verdikleri yanıtlardan yapılan doğrudan alıntılara aşağıda yer verilmiştir.

"Daha düzenli bir hayat sağlar işinin olması. Diğer şekilde insan çelişki içinde kalır. Bir şey yapacaktır mesela 'Yapsam mı acaba yapmasam mı?' diye düşünür" (A1, 2,1).

"Insanlar kendilerini daha özgür, daha verimli, daha üst seviyeye getirmek için çalışmak istiyorlar" (A2, 2,1).

"Insanları bence ruhen rahatlatan bir şey çünkü işsiz olduğunuz zaman hani özellikle üniversiteden mezun olunca bir boşluk oluyor. Hani, ben neyim? Öğrenci değilim. Bir yerde çalışıyor muyum? Hayır, çalışmıyorum. Hani, bu ister istemez insanda hani bir boşluk yaratıyor, benim açımdan öyle. O yüzden bence ruhen iyi gelen bir şey" (A3, 2,1).

"İs yaşamı ilk başta ekonomik özgürlüğ̈̈ sağllyor. Kendi ayaklarının üzerinde duruyorsun, istediğin her şeyi yapabiliyorsun ve hesap verme olgusu olmadan yapabiliyorsun. Bu insanın kendine güveni açısından da çok önemli bir şey. Benim bu 2 yl içerisinde en önemli şey kendime güvenim çok gitti çünkü hep birilerine bağımlıyım” (B2, 2,1).

“Özgürlük. İnsanın ekonomisi olunca, alım gücü olunca özgür oluyor. Alım gücü olmadı̆̆ zaman başkalarına bă̆ımlı olarak yaşıyorsun” (B3, 2,1).

Varoluş gereksinimi kategorisine ilişkin katılımcıların verdikleri yanıtlardan yapılan doğrudan alıntılara aşağıda yer verilmiştir.

“Önemli, insan yaşamında bence önemli bir şey çünkü hani iş olmadı̆̆ zaman maddi manevi büyük bir sıkıntı olduğunu düşünüyorum. Hani, madden bir şey kazanmiyorsun. Yaşayabilmen için de bir şeyleri harcaman gerekiyor. Öyle bir sorun oluyor yani, o yüzden önemli. Çok önemli”(A3, 2,2). 
"Yaşamı devam ettirebilmek açısından bence en önemli faktörlerden biri. IŞ̧ olmazsa insan bir süre sonra sılkılmaya başlıyor. Bir şeyle uğraşması kazanç elde etmesi onu motive ediyor bence (B4, 2,2).

"Öncelikle maddi anlamda önemi çok büyük çünkü maddiyatın olmazsa özgüvenin de yerinde olmuyor iş yaşaminda olunca özgüvenimiz yerinde oluyor. Kimseye bir ihtiyacımızın olmadığını düşünüyoruz. Özellikle kadınlar için iş yaşamı ayakta durabilmesi için çok önemli” (C4, 2,2).

"IŞs yaşamı insanların hayata atılması, hayatını kurması, bu konuda kendi ayakları üzerinde durması için gerekli yaşam. Çünkü işiniz olmadan hiçbir şey yapamıyorsunuz, çünkü ya aileniz yanınızda olacak bir şekilde hayatınızı devam ettirmek için aileniz size destek çıkacak ya da bir yerden bir kazancınızın olması lazım yoksa yaşamak zor" (DI, 2,2).

"Hayatını idam ettirmek, para kazanabilmek, ihtiyaçlarını karşılayabilmek, ekonomik, sosyal ihtiyaçlarını karşılayabilmek. Ben iş yaşamını öyle görüyorum" (D3, 2,2).

Para kazanmak kategorisine ilişkin katılımcıların verdikleri yanıtlardan yapılan doğrudan alıntılara aşağıda yer verilmiştir.

“...Bir şey yapacaktır mesela 'Yapsam mı acaba yapmasam mı?' diye düşünür. İlk önce cebini düşünür. Maddiyat öndedir onun gibi” (A1, 2,3).

"Yani bir gereklilik artık bu çünkü para olmadan bu ülkede yaşamak biraz zor oldu. O şekilde yani, insanların bir ihtiyacı olarak olmazsa olmaz" (B1, 2,3).

"Gelir kaynă̆ı olduğu için son derece önemli zaten ev geçindirmek olsun şu an her şey parayla dönüyor" (Cl, 2,3).

"Bir kere ilk başta maddiyat olarak önemi vardır. Kişinin kendini geçindirebilmesi en önemli sebeplerden biridir" (C3, 3).

"Öncelikle maddi anlamda önemi çok büyük çünkü maddiyatın olmazsa özgüvenin de yerinde olmuyor iş yaşamında olunca özgüvenimiz yerinde oluyor” $(C 4,3)$.

Amaçlı yaşam kategorisine ilişkin katılımcıların verdikleri yanıtlardan yapılan doğrudan alıntılara aşağıda yer verilmiştir.

"Değişim olur çalıştı̆̆ın zaman. Fikrin daha rahattır, sorunlar yaşamiyorsun o açıdan. Ondan sonra belli bir miktarda hedef koyduğunuz şeyi yapabiliyorsunuz çünkü işiniz var" $(A 4,2,4)$.

“...insanların tatmin olma duygusu yani başarma duygusu. İnsanlar başardıkça mutlu oluyor yani aslında işe girmenin tek sebebi bu, başarma duygusunu gerçekleştirmek..." (D2, 2,4).

Katılımcıların iş yaşamının insanlar için önemiyle ilgili görüşleri değerlendirildiğinde, özellikle şehirlerde yaşamın devam ettirilmesinin bir işe sahip olarak maddi kazançla mümkün olduğu, işin özgürlük, özgüven ve özsaygı duygusu verdiği, geleceğe yönelik amaç ve hedef oluşturmada insan hayatında bir zorunluluk olduğu ortaya çıkmaktadır.

İşsizliğin bireyler üzerindeki ekonomik, sosyal ve psikolojik etkilerine yönelik katılımcılardan alınan yanıtlar aşağıda tablolar eşliğinde sunulmuş ve doğrudan alıntılara yer verilmiştir. 
Tablo 3. İşsizliğin neden olduğu ekonomik sorunlar temasına göre oluşturulan kategoriler

\begin{tabular}{|c|c|c|c|c|c|c|c|c|c|c|c|c|c|c|c|c|c|c|c|}
\hline & \multicolumn{19}{|c|}{ Katılımcılar } \\
\hline & & A & A & A & A & B & B & B & B & C & C & C & C & D & $\mathrm{D}$ & D & $\mathrm{D}$ & & \\
\hline & Kategoriler & 1 & 2 & 3 & 4 & 1 & 2 & 3 & 4 & 1 & 2 & 3 & 4 & 1 & 2 & 3 & 4 & $\mathrm{f}$ & $\%$ \\
\hline 1 & $\begin{array}{l}\text { Yaşamsal } \\
\text { Gereksinimleri } \\
\text { Karş1layamamak }\end{array}$ & & & & & $\sqrt{ }$ & & $\sqrt{ }$ & & $\sqrt{ }$ & & $\sqrt{ }$ & $\sqrt{ }$ & & & & $\sqrt{ }$ & 7 & 43.7 \\
\hline 2 & $\begin{array}{l}\text { Aileye Yük Olmak ve } \\
\text { Ekonomik Bağlılık }\end{array}$ & & $\sqrt{ }$ & $\sqrt{ }$ & & $\sqrt{ }$ & $\sqrt{ }$ & & & & & & & $\sqrt{ }$ & & & & 5 & 31.2 \\
\hline 3 & $\begin{array}{l}\text { Geçim Sikıntıs1 } \\
\text { Yaşamak }\end{array}$ & & & & & $V$ & & & $\sqrt{ }$ & & & & & & & $\sqrt{ }$ & & 3 & 18.7 \\
\hline
\end{tabular}

Tablo 3'de görüldüğü gibi katılımcıların önemli bir kısmı \%43.7'si işsizlik nedeniyle yaşamsal gereksinimlerini karşılayamadıklarını \%31.2'si aileye yük olduklarını ve ekonomik bağlılık içinde olduğunu ve \%18.7'si geçim sıkıntısı yaşadığını belirtmiştir. Buna göre katılımcılardan doğrudan alınan yanttlar incelendiğinde;

“...Ev geçimi, alışveriş olsun, elektrik, su, doğalgaz, telefon, internet bunların hiçbirini karşılayamıyorsun. İş bir mecburiyete dönüyor...” (B1, 3,1).

“...Sonuçta o evin elektriği, suyu, gazı var bunlar ödenemez işsizken bunların ödenmesi gerekiyor ama ben de de şöyle bir şey oluyordu dışarı çıkacă̆ım mesela veya almak istediğim şeyler var arkadaşlarımla gezmek bir şeyler içmek bunların hepsi parayla olduğu için bunları yapamıyorsun doğal olarak...” (C1, 3,1).

"Kendi ihtiyaçlarımı karşılayamıyorum en öncelikli olarak bu bir gezmede olabilir, ihtiyaç alışverişi de olabilir her türlü insanın kendiyle ilgili ihtiyaçlarını karşılayamaması oluyor ve bu birine muhtaç durumunda olmasına sebep oluyor" $(C 3,3,1)$.

"Şu an kendi ihtiyaçlarımı karşılamakta zorlanıyorum işin gerçeği. Yine kısa vadeli işler yapıyorum ama yetmiyor tabii ki de. Kirayd, elektrikti, suydu bir sürü problem, dert. Onları karşılamak, karşılamakta güçlük çekiyorum” (D4, 3,1).

Katılımcılardan işsizlik nedeniyle kendilerini ailelerine yük ve ekonomik bağlılık içinde görenlerin yanıtlarından yapılan doğrudan alıntılara aşağıda yer verilmiştir.

"Şöyle maddi sorunlar yaşıyorum; dul olduğum için iki tane evladım var, yeteri kadar nafaka bağlandı ama ben işsiz olduğum için o nafakayı ödeyemiyorum. Şu an toplam 100.000 liraya yakın nafaka borcum var 10 yıldır. Ailemin yanında yaşıyorum. Ailem olmazsa bittim, böyle bir durum” (A2, 3,2).

"Geçim yani sonuç olarak işsiz olduğunuz zaman haliyle aileye bir bağımlılık oluyor. Aileye bağll olmak da psikolojik açıdan da yoruyor insanı. Yani hem günlük gereksinimlerin olsun ya da yapman gereken özel gereksinimlerin olsun hiçbir şeyi karşılayamıyorsun" (B1, 3,2).

“... Ailemden dediğim gibi evden dışarı çıkarken bir yere gideceksem yol parası, market parası, arkadaşlarımla buluşacaksam hani yemek parasıydl, üstüme başıma bir şey almam gerekiyor işte klyafet o bu... Bunları alırken para altyorsunuz... Aileye tabi olunca hiçbir şeyiniz yok demek. Evde yaşamak zorundasınızdır...” (B2, 3,2).

Araştırmadaki işsiz katılımcıların \%18.7'si ekonomik sorunların kendilerinde geçim sıkıntısı yarattığını açıklamıştır. Katılımcıların bu yöndeki açıklamalarına doğrudan alıntı yapıldığında şu yanıtlar elde edilmiş̧ir:

“Geçim yani sonuç olarak işsiz olduğunuz zaman haliyle... hem günlük gereksi- 
nimlerin olsun ya da yapman gereken özel gereksinimlerin olsun hiçbir şeyi karşılayamıyorsun. Ev geçimi, alışveriş olsun, elektrik, su, doğalgaz, telefon, internet bunların hiçbirini karşılayamıyorsun..." (B1, 3,3).

"Bence herkes için işsizlik bir sorun günümüz şartlarında yani işsiz olarak kolay değil bir aile geçindirmek" (B4, 3,3).

"Ben kendimden, yaşadıklarımı anlatayım. Evlilik sonrası boşanmalar olabilir, bankalarla problemler yaşıyorsunuz, işiniz sürekli olmadığ zaman kredilerde problemler yaşıyorsunuz" (D3, 3,3).

Katılımcıların işsizliğin neden olduğu ekonomik sorunlarla ilgili görüşleri, ekonomik sorunların temel yaşamsal gereksinimler olan gıda, giyim, ulaşım, barınma, iletişim vb. karşılayamamaktan, bankalardan alınan kredilerin ödenememesi nedeniyle geçim sorunlarına ve ebeveynlerden maddi destek almak zorunda kalarak kendilerini yük olarak hissetmeye kadar çeşitlilik içerdiği ifade edilebilir.

Tablo 4. İşsizliğin neden olduğu sosyal sorunlar temasına göre oluşturulan kategoriler

\begin{tabular}{|c|c|c|c|c|c|c|c|c|c|c|c|c|c|c|c|c|c|c|c|}
\hline & \multicolumn{19}{|c|}{ Katılımcılar } \\
\hline & & A & A & A & A & B & B & B & B & C & $\mathrm{C}$ & $\mathrm{C}$ & C & $\mathrm{D}$ & $\mathrm{D}$ & $\mathrm{D}$ & $\mathrm{D}$ & & \\
\hline & Kategoriler & 1 & 2 & 3 & 4 & 1 & 2 & 3 & 4 & 1 & 2 & 3 & 4 & 1 & 2 & 3 & 4 & $\mathrm{f}$ & $\%$ \\
\hline 1 & $\begin{array}{l}\text { Sosyal Faaliyetlere } \\
\text { Katılamamak }\end{array}$ & $\sqrt{ }$ & $\sqrt{ }$ & & & $\sqrt{ }$ & & $\sqrt{ }$ & $\sqrt{ }$ & & & $\sqrt{ }$ & $\sqrt{ }$ & & & $\sqrt{ }$ & & 8 & 50.0 \\
\hline 2 & Toplumsal Bask1 & & & $\sqrt{ }$ & & & $\sqrt{ }$ & & & & $\sqrt{ }$ & & & & & & & 3 & 18.7 \\
\hline 3 & $\begin{array}{l}\text { Arkadaşlardan } \\
\text { Uzaklaşmak }\end{array}$ & & & & & & & & & $\sqrt{ }$ & & & & & $\sqrt{ }$ & & & 2 & 12.5 \\
\hline 4 & $\begin{array}{l}\text { Evlenememek ve } \\
\text { Boşanmak }\end{array}$ & & & & & & & & & & & & & $\sqrt{ }$ & & $\sqrt{ }$ & & 2 & 12.5 \\
\hline
\end{tabular}

Tablo 4'de görüldügü gibi, katılımcıların işsizliğin sosyal sorunlar temasına verdikleri yanıtlardan \%50'si sosyal faaliyetlere katılamamak, \%18.7'si toplumsal bask1, \%12.5'i arkadaşlardan uzaklaşmak ve yine \%12.5 oranında evlenememek ve boşanmak yönünde sorun oluşturduğu görüşünde birleşmiştir. Aşağıda bu tema doğrultusunda bazı katılımcılardan alınan yanıtlara doğrudan alıntı yapılmıştır.

“...bazı aktivitelere katılmak gerekiyor ama bu seferde onun için de para gerekiyor. İs para olayına dönüyor yine. Evden çıkacaksın, arabana yakıt. Bir kafeye oturacaksın, içtiğin çaya suya para. Her şekilde para, para, para olayına döndüğü için yani insan evden çıkmaya bir müddet sonra çekiniyor. Yani, her şeyini etkiliyor senin işsizlik" (A1, 4,1).

"Hiçbir sosyal hayatım yok. En kısa cevabım bu çünkü sosyalleşebilmen için belli bir kazancin olmast gerekiyor" (A2, 4,1).

"Para olmadiğı zaman yine de etkileniyor sosyal yaşam ama yine de bir şekilde yaşlyorsun" (B1, 4,1).

"Tiyatro, sinema o gibi yerler yok. Yaz tatili yok. Eğlence yok" (B3, 4,1).

"Sosyalleşmiyoruz çok fazla. Daha çok ne demeliyim gitmek istediğimiz konser olur tiyatro olur bir şey olur erteliyorsunuz" (B4, 4,1).

"Örneğin bir sanat topluluğuna katılamamak. Bir arkadaşımızın doğum gününe gitsek de istediğimiz tarzda hediye alıp orada bir şey yiyip içememek aslında ya da sinemaya gidememek" $(C 3,4,1)$.

"Anti sosyal oluyorsunuz, spor aktiviteleriniz azallyor çünkü o da tamamen ekonomiye yönelik. Sosyalliğimizi ekonomik etkiliyor. Eski milli yüzücüyüm, paranız olmadığı zaman bir tesise girip orayı kullanamıyorsunuz" (D3, 4,1). 
İşsizliğin neden olduğu sosyal sorunlardan ikincisi toplumsal baskı kategorisi adında oluşturulmuş olup, katılımcıların bu kategoriye yönelik yanıtlarından aşağıda doğrudan alıntı yapılmıştır.

"Mahalle basklsı...Mahalle baskısı da şöyle oluyor; Türkiye'de yaşıyoruz biliyorsunuz hani üniversite okuyana kadar üniversiteye gir, gir, gir... Üniversiteye girersin bitir, bitir, bitir... Bitti hadi evlen, evlen, evlen... Hani böyle bir sirkülasyon var o yüzden hani o da biraz şu an evlilik diye sürükleniyorum. Ama şu an istemiyorum. Ama öyle oluyor. Madem çalışmıyorsun bari evlen hani bari evlen, çocuk yap, çocuk bak kafası. O da kötü bir şey bence” (A3, 4,2).

"Sosyal sorunlar şu var bende en büyük şey şu; mesela bayrama geldiğinizde bile sen hala işsiz misin, o kadar okudun bir şey olamadın mi, hiçkimse sana iş vermiyor mu, nasl bir bölüm okuduysan, demek ki ahmak bir bölüm okudun... Bir de ben bunu hiç sevmiyorum. Bu beni ylkan bir şey. 4 sene okudum ve demek ki sen ahmak bir bölüm okudun. Herkes bir şeyler oluyor sen niye olamadin? Demek ki hani kötüydü, okumak için okudun bir şeyler... Ya okudum, bu devirde üniverisite okuyan herkes bir şeyler okumuş zaten didinmiş. E bulamıyor zaten çok mezun var hani bizim suçumuz yok burada. Bu hani bir vasıfsı muamelesi yapılmasl, sürekli beni küçümsemeleri ve açıkçası insan yerine de koymuyorlar. Söz hakkınız yok gibi davranılyyor size. Çünkü niye? Senin ekonomik gücün yok, sen karışma. Sen bir dur. Önce biz bir fikrimizi söyleyelim sen bir şey deme. Hani etkisiz elemanmışım gibi” (B2, 4,2).

"Baskl oluyor bir de insanın üzerinde akrabalar olsun anne baba olsun niye bu kadar okuyor da okuduktan sonra niye işsiz hala diyebiliyor bu da ister istemez insant siklyor" (C2, 4,2).

İssizliğin neden olduğu sosyal sorunlardan bir diğeri arkadaşlardan uzaklaşmak kategorisi adında oluşturulmuştur. Katılımcıların bu kategori ile ilgili görüşlerine doğrudan alıntılar yapılarak aşağıda yer verilmiştir.

"Mesela arkadaşlarımla vakit geçiremiyorum birçok etkinlik parayla olduğu için gidemiyorsun. Onun öncesinde bir yemek yeniyor falan derken bunlarl yapamiyorsun, katılamiyorsun" (C1, 4,3).

“İnsanlar arasına karlşamıyorum, en büyük sorun bu. Herkesin bir arkadaş ortamı var, herkesin işi olduğu için para kazandiğı için belirli bir aktiviteleri yaparken senin bunu yapamiyor olman anlamina geliyor" (D2, 4,3).

İşsizliğin neden olduğu sosyal sorunlardan dördüncüsü evlenememek ve boşanmak kategorisi adında oluşturulmuştur. Katılımcıların bu kategori ile ilgili görüşlerine doğrudan alıntılar yapılarak aşağıda yer verilmiştir.

"Ben sosyal sorunlar yaşamadım ama benim çevremde çok arkadaşım var. Mesela işsizliğinden dolay evlenemedi, işsizliğinden dolayı kendine güvensizlik oluşturuyor ve arkadaşlarıyla buluşmak istemiyor" (DI, 4,4).

"Ben kendimden, yaşadıklarımı anlatayım. Evlilik sonrası işsizlik nedeniyle boşanmalar olabilir..." (D3, 4,3).

Katılımcıların görüşleri doğrultusunda işsizliğin bireyler üzerinde yol açtığı sosyal sorunlar; Toplumdan dışlanmışlık hissi, asosyal davranmaya zorlanma, para harcamayı gerektiren sosyal ortamlardan uzak durma, insanlarla ilişkilerde konunun işsizliğe gelmesi nedeniyle baskı altında kalmışlık hissi, evlenmeyi sürekli ertelemek zorunda kalma veya ekonomik geçimsizlik nedeniyle boşanma olarak açıklanabilir. 
Tablo 5. İşsizliğin neden olduğu psikolojik sorunlar temasına göre katılımcıların görüşleri

\begin{tabular}{|c|c|c|c|c|c|c|c|c|c|c|c|c|c|c|c|c|c|c|c|}
\hline & \multicolumn{19}{|c|}{ Katılımcılar } \\
\hline & & $\mathrm{A}$ & $\mathrm{A}$ & $\mathrm{A}$ & $\mathrm{A}$ & B & $\mathrm{B}$ & $\mathrm{B}$ & $\mathrm{B}$ & $\mathrm{C}$ & $\mathrm{C}$ & $\mathrm{C}$ & $\mathrm{C}$ & $\mathrm{D}$ & $\mathrm{D}$ & $\mathrm{D}$ & $\mathrm{D}$ & & \\
\hline & Kategoriler & 1 & 2 & 3 & 4 & 1 & 2 & 3 & 4 & 1 & 2 & 3 & 4 & 1 & 2 & 3 & 4 & $\mathrm{f}$ & $\%$ \\
\hline 1 & Üzüntü & & & & & $\sqrt{ }$ & & & & & & $\sqrt{ }$ & $\sqrt{ }$ & & & & $\sqrt{ }$ & 4 & 25.0 \\
\hline 2 & Özgüven Kayb1 & & $\sqrt{ }$ & & & & & & & & & & & $\sqrt{ }$ & $\sqrt{ }$ & & & 3 & 18.7 \\
\hline 3 & Tahammülsüzlük & & & & & & $\sqrt{ }$ & & & & & $\sqrt{ }$ & & & $\sqrt{ }$ & & & 3 & 18.7 \\
\hline 4 & İçe Kapanma & & & & & & & & & $\sqrt{ }$ & $\sqrt{ }$ & & & & $\sqrt{ }$ & & & 3 & 18.7 \\
\hline 5 & Stres & & & & $\sqrt{ }$ & & & & & & & $\sqrt{ }$ & & $\sqrt{ }$ & & & & 3 & 18.7 \\
\hline 6 & Depresyon & & & $\sqrt{ }$ & & & & & & & & & & & & $\sqrt{ }$ & & 2 & 12.5 \\
\hline 7 & Değersizlik & & & & & & $\sqrt{ }$ & & & $\sqrt{ }$ & & & & & & & & 2 & 12.5 \\
\hline 8 & Mutsuzluk & & $\sqrt{ }$ & $\sqrt{ }$ & & & & & & & & & & & & & & 2 & 12.5 \\
\hline 9 & Yetersizlik & & & & & $\sqrt{ }$ & & & & & & & & & $\sqrt{ }$ & & & 2 & 12.5 \\
\hline 10 & Uykusuzluk & & & $\sqrt{ }$ & $\sqrt{ }$ & & & & & & & & & & & & & 2 & 12.5 \\
\hline
\end{tabular}

Tablo 5'de katılımcıların işsizliğin neden olduğu psikolojik sorunlara verdikleri yanıtlar doğrultusunda 10 farklı psikolojik sorun belirlenmiştir. Bunlardan üzüntü \%25 ile katılımcılar tarafindan en fazla açıklanan psikolojik sorun iken \%18.7 ile özgüven kaybı, bunu aynı oranda tahammülsüzlük, içe kapanma ve stres izlemiştir. Depresyon, değersizlik, mutsuzluk, yetersizlik ve uykusuzluk \%12.5 oranıyla takip etmiştir. Bazı katılımcıların işsizliğin neden olduğu psikolojik sorunlara ilişkin görüşlerine aşağıda doğrudan alıntı yapılarak yer verilmiştir.

"Uykusuzluk, bu var mevcut. Bazen hani ortada hiçbir şey yokken bir depresif hale girebiliyorum. Hani yani, bugün mutluyum. Yarın depresif halde olabiliyorum. Böyle mutsuz, uf ne yapacağım ya kalkıp ne yapacağım ya kafa o yani. Yapacak bir işim yok, evde oturup ne yapacağım diye yani şey yapıyorum açıkçası o tarz bir psikolojik sorun yaşlyorum" (A3, 5,10,6,8).

"Işte tek psikolojik sorun yaşadı̆̆ım aileye bağlı olmak. Bu biraz bizi etkiliyor çünkü...belli bir yaşa geldikten sonra bu insan için biraz babasından annesinden para istemek biraz insanı üzüyor yani" (B1, 5,1).

"Sanki hiç iş bulamayacakmışım gibi geliyor bu da kaygı problemine yol açıyor benim için bu da çevremdeki insanları gördükçe ve bu genç yaşta iş bulamamak beni daha da çok üzüyor. Artık her gün bunu düşünmeye başlyyorum her gün. Sürekli bu düşünce halindeyim bulabilecek miyim stresi oluşuyor etrafimdaki ilişkileri de etkiliyor. Bu şekilde sıkıntılı bir dönemden geçiyorum. Daha çok stresli oluyorum bu sikıntıl dönem de bir şeye tahammül edemiyorum evde oturuyorsun her gün..” (C3, 5,1,5,3).

"ISssizlik sebebiyle dediğim gibi özgüven kaybı oluşuyor insanda. Diyorsunuz "acaba bu böyle mi devam edecek?" biraz stresli oluyorsunuz, "ben ne yapacağım, ne yapmam gerekiyor, başka yöne mi yönelsem?" kesinlikle özgüven kaybı oluşuyor insanda" $(D 1,5,2,5)$.

"Insanların sana ilgisi düşünce yetersiz hissediyorsun. Yetersiz hissedince de ilerleyen süreçlerde kabuğuna çekildiğin için insanlarla olan iletişimin de azallyor. Bir iş görü̈şmesi yaptı̆̆ın zaman kendine olan güvenin azaldiğ için işin kabul olma oranı da çok düşüyor bu da işsiz kalma süreci devam ettikçe bu daha da zorlaşıyor. Daha çok sinirleniyorsunuz, karşı taraftaki insanlara daha çok tahammülsüz oluyorsunuz her şey size dokunuyor yani herhangi bir, bir kelime, bir söz...” (D2, $5,9,4,2,3)$.

Katılımcıların yanıtlarından işsizliğin insanların psikolojik sağlı̆̆ üzerinde olumsuz etkide bulunan dikkate alınması gereken önemli bir sorun olduğu anlaşılmaktadır. Özellikle katılımc1- 
lar uzayan işsizlik sürecinin kendilerinde stresi yoğunlaştırdığını ve kaygı düzeyini artırdığını, bu durumun kendilerinde hem psikolojik hem de fizyolojik olarak yıpratıc1, örseleyici ve tahrip edici olduğunu açıklamıştır. İşsiz arkadaşıyla beraber kaldığını açıklayan katılımcılardan biri arkadaşının ağır depresyon içerisinde olduğunu, intihar etmesinden korktuğunu söylerken, işsizliğin neden olduğu yoğun kaygı ve stres nedeniyle kendisinin de psikolojik destek aldığını itiraf etmiştir.

Aşağıda Tablo 6'da İşsizliğin neden olduğu sonuçlara yönelik katılımcıların görüşlerine yer verilmiştir.

Tablo 6. İşsizliğin neden olduğu sonuçlar temasına göre oluşturulan kategoriler

\begin{tabular}{|c|c|c|c|c|c|c|c|c|c|c|c|c|c|c|c|c|c|c|c|}
\hline & \multicolumn{19}{|c|}{ Katılımcılar } \\
\hline & & A & & A & A & B & B & B & B & $\mathrm{C}$ & $\mathrm{C}$ & $\mathrm{C}$ & $\mathrm{C}$ & $\mathrm{D}$ & $\mathrm{D}$ & $\mathrm{D}$ & $\mathrm{D}$ & & \\
\hline & Kategoriler & 1 & 2 & 3 & 4 & 1 & 2 & 3 & 4 & 1 & 2 & 3 & 4 & 1 & 2 & 3 & 4 & $\mathrm{f}$ & $\%$ \\
\hline 1 & Bireysel Sonuçlar & $\sqrt{ }$ & & & $\sqrt{ }$ & & $\sqrt{ }$ & & & $\sqrt{ }$ & $\sqrt{ }$ & & $\sqrt{ }$ & $\sqrt{ }$ & $\sqrt{ }$ & & & 8 & 50.0 \\
\hline 2 & Toplumsal Sonuçlar & $\sqrt{ }$ & & $\sqrt{ }$ & $\sqrt{ }$ & $\sqrt{ }$ & & & & & & $\sqrt{ }$ & & & & & & 5 & 31.2 \\
\hline
\end{tabular}

Tablo 6'dan anlaşılacağı gibi işsizliğin neden olduğu sonuçlar temasına ilişkin iki kategori oluşturulmuştur. Katılımcıların yarısı işsizliğin neden olduğu bireysel sonuçlar üzerinde dururken, \%31.2'si toplumsal sonuçlar doğrultusunda görüş belirtmiştir. Bu tema doğrultusunda bazı kat1lımcıların görüşlerine yönelik doğrudan alıntılara aşağıda yer verilmiştir.

"Ya işsizlik, iş demek zaten senin her şeyindir. Bir işin olursa hayatını devam ettirebilirsin ama işsizlik özellikle; bir evli çift için ayrılık nedeni, çocuklu bir çift için mutsuz bir hayat” (A1, 6,1,2).

...insanlar işsizlik yaşadiğı zaman kötü oluyor. En büyük sıkıntı kendisinde oluyor ondan sonra çevresindeki insanlarda oluyor. Psikolojik durumunda mesela bilmiyorum çok şeyler var. Mesela kafana bir şey koymuşsun bir iş yapacağım. Olmayınca işsizsin ondan sonra evde çocuklarla tartışıyorsun, eşinle tartışıyorsun. Psikolojik anlamda çok kötü oluyor” (A4, 6,1,2).

"İssizlik hem insanı psikolojik olarak zedeleyen bir şey hem de geçim kaynağı sağlayamadiğın için yani doğal olarak kendi içine kapanma durumu oluyor. Moral bozukluğuna sebep oluyor" (C1, 6,1).

"insanlar hani işsiz olduğu için başka taraflara yönelebiliyor bu da hem ahlaki hem sosyal açıdan olumsuz etkileniyoruz. O yüzden hani işsizlik bence ülkeyi kötü taraflara götüren bir şey” (A3, 6,2).

“...bu zaten beyin göçüne sebep oluyor bence bizim yaş aralığımızdaki jenerasyon burada iş bulamayınca şu an yurt dişının verdiği imkanlardan dolayı bir kere göç veriyor yani Türkiye bu da Türkiye için de kötü bir şeydir bence" (C3, 6,2).

İşsizlik her ne kadar bireysel düzlemde yaşanan bir sorun olsa da işsizliğin yarattığı ekonomik, psikolojik ve sosyal problemler bireyin yakın çevresini ve hatta tüm toplumu da etkileyebilir. Katılımcılar işsizliğin yarattı̆̆ moralsizliğin veya öfkenin çoğu zaman çocuklara, eşe, akrabalara şiddet eğilimine dönüştügünü, ahlaki problemleri ortaya çıkardığını ve ülke kalkınmasını etkileyen beyin göçünün önemli nedenlerinden biri olduğunu öne sürmektedirler.

Katılımcıların işsizlik sorunu için çözüm önerilerine yönelik görüşleri aşağıdaki tabloda sunulmuştur. 
Tablo 7. İşsizlik için çözüm önerilerine yönelik görüşler temasına göre oluşturulan kategoriler

\begin{tabular}{|c|c|c|c|c|c|c|c|c|c|c|c|c|c|c|c|c|c|c|c|c|}
\hline & \multicolumn{20}{|c|}{ Katılımcılar } \\
\hline & & $\mathrm{A}$ & & $\mathrm{A}$ & A & $\mathrm{B}$ & $\mathrm{B}$ & B & B & $\mathrm{C}$ & $\mathrm{C}$ & $\mathrm{C}$ & $\mathrm{C}$ & $\mathrm{D}$ & $\mathrm{D}$ & $\mathrm{D}$ & $\mathrm{D}$ & & & \\
\hline & Kategoriler & 1 & 2 & 3 & 4 & 1 & 2 & 3 & 4 & 1 & 2 & 3 & 4 & 1 & 2 & 3 & 4 & & $\mathrm{f}$ & $\%$ \\
\hline 1 & $\begin{array}{l}\text { Eğitim Stratejisi } \\
\text { Oluşturulmas1 }\end{array}$ & & & $\sqrt{ }$ & & & $\sqrt{ }$ & $\sqrt{ }$ & $\sqrt{ }$ & $\sqrt{ }$ & & $\sqrt{ }$ & $\sqrt{ }$ & $\sqrt{ }$ & $\sqrt{ }$ & $\sqrt{ }$ & & & 10 & 62.5 \\
\hline 2 & $\begin{array}{l}\text { İşe Alımlarda } \\
\text { Adil Tutum }\end{array}$ & $\sqrt{ }$ & & $\sqrt{ }$ & $\sqrt{ }$ & & $\sqrt{ }$ & & & & & $\sqrt{ }$ & $\sqrt{ }$ & & & & & $\sqrt{ }$ & 7 & 43.7 \\
\hline 3 & $\begin{array}{l}\text { İstihdam Politikası } \\
\text { Oluşturulması }\end{array}$ & & $\sqrt{ }$ & & & $\sqrt{ }$ & & & & $\sqrt{ }$ & $\sqrt{ }$ & & & & & & & & 4 & 25.0 \\
\hline
\end{tabular}

Tablo 7'de görüldüğü gibi işsizliğin çözümüne yönelik görüşler teması doğrultusunda katılımcıların büyük bir çoğunluğu \%62.5'i eğitim stratejisi oluşturulması yönünde görüş belirtmiştir. Katılımcıların \%43.7'si işe alımlarda adil tutum oluşturulması bağlamında açıklama yapmıştır. Bu tema altındaki üçüncü kategori ise istihdam politikası oluşturulmasıdır, katılımcıların \%25'i bu yönde görüş belirtmiştir. Bu tema ve oluşturulan kategoriler doğrultusunda aşağıda katılımcıların görüşlerine doğrudan alıntılar yapılarak yer verilmiştir.

“...üniversitelerde mesela benim gibi olan bir sürü arkadaşım var ve diyetisyen çok fazla mezun olduk. O yüzden de bir süre örnek veriyorum hani durdurulmalı alım ya da bu kadar çok üniversite açılmamalı bence... Bir de gerçekten şu iş tecrübesi olayı beni bitiren bir nokta. E sen verme o vermesin iş tecrübesi kazanamazsin. Öyle şeyleri kaldırmalarl gerekiyor. Beni bir denesin zaten hani kimse ilk başladığ zaman beni şu mertebeye çıkarın diye bir şey demiyor. Ama insanlar da böyle bir sikıntı da var maalesef." (A3, 7,1,2).

"İssizlik sorunu için bir kere işverenlerin daha fazla olması gerekiyor veyahut daha fazla sektörlere atılım yapılması gerekiyor veya devletin özel sektörü desteklemesi gerekiyor veya devletin kendi yapacağı adımlarla olur... İste istihdam sağlaması lazım yani. Yeni yerler, yeni üretim tesisleri açması gerekiyorken aslında şu an tam tersini yapıyor özelleştirerek, satarak. Tabi yabancı ülkelere satıldiğ zaman adam kendi işçisini getiriyor haliyle. Yine Türkiye'de işsizlik oluyor bunun önüne geçilmesi gerekiyor. Dediğim gibi biraz genç nüfusa önem verilmeli. Hani daha çok tecrübelilerin alınması değil de tecrübelendirilip genç nüfusun katkıda bulunmasi gerekiyor" (B1, 7,3,2).

"İssizlik sorunu için ben ilk çözümün artık üniversiteye alımların azaltılması. Kesinlikle üniversiteye ya 500 kişi mi alıyorsun al 50 kişi al. Daha fazlasını alma yani. Hani bırak, insanlar sonradan yıkıma uğramasın baştan uğrasın yani. Ya da alıyor musun bölümde ona yönelik bir şirket aç yani insanların bir yerlere faydalı olabileceği bir şey aç. Birine 5000 verip birine 2000 verme. Ortada bir maaş belirle daha çok insan al yani, hani. Ya da bölümü kapat, toptan kapat yani. Bu bölümden daha işçi, memur almayacak misın? Kapat bu bölümü o zaman yani. Üniversiteye gireriz dedik mezun olunca. Yüksek lisansımızı yaptı, o, bu... Üniversiteye sadece ben girmek istemiyorum ki milyonlarca kişi istiyor belki de. Torpildi, tanıdıktı. Ya bir liyakat sistemi olsun. Başarılı olan alınsın artık, yok. Biz, taşrada oturan bir insanım ben yani. Yok benim tanıdı̆ı̆m. Nerden olabilir yani? Ben bunların da önüne geçilsin istiyorum. Yazılı sınavı bir şekilde başarıyoruz. Mülakat... Ben KPSS'den iyi puanlar aldım sonra kurumların mülakatlarında hep elediler beni. Niye? Tanıdığımız yoktu. Bir şekilde başarısı mı oldum? Yok, olmadım. Bilgi anlamında hiçbir şeyim yoktu ama hep böyle şey olduk. O yüzden ben birazcık da bilgisi olanın alınmasinı istiyorum yani hani. Gerçekten bilgiye 
değer verilsin. Bu insan bu pozisyonda yapabilir mi? Yani kapasitesine, zekasına, kıvraklı̆̆ına... Bunların hepsi bir arada ölçülsün istiyorum. Belki bu şekilde daha aza indirebiliriz diye düşünüyorum” (B2, 7,1,3,2).

“Özellikle diplomalı mezunlar için özellikle fazla ögrenci alan bölümlerin kapasitelerinin azaltılması gerekiyor ya da benim en çok başıma gelen şey özel okullara başvurduğum zaman bana diyorlar ki tecrübe istiyoruz ben bir yere başlamadan tecrübe nasil kazanabilirim. En azından gençlere şans vermeleri gerekiyor bir firsat taninsin ki tecrübe kazanabilsin insanlar bence buna çözüm bulunmalı $(C 4,7,1,2)$.

"ilk önce çok önceden başlatılması gerekiyor, önceden başlatılması demek; ilko$\mathrm{kul}$, liseden itibaren başlayıp insanları meslek edinme çabasiyla devam etmesi lazım. En çokta öğrencileri üretme çabasıyla ilerletmek gerekiyor. Üreten insan mutlaka başkalarına da iş imkanı sağlayacaktır" (D2, 7,1).

İşsizliğin çözümüne yönelik katılımcıların görüşlerinden; istihdam edilenden daha fazla öğrencilerin mezun olduğu üniversitedeki bölümlere ya öğrenci alınmaması ya da kapatılması yönünde ve temel eğitimden itibaren üniversite eğitimini özendirmek yerine bireylere meslek edindirmeyi amaçlayan eğitim stratejisi uygulanması gerektiği. Devletin yeni istihdam alanları, üretim alanları açarak, özel sektörü üretmeye ve yatırım yapmaya teşvik etmesiyle istihdam ihtiyacını artıracak politikalar izlemesinin önemli olduğu. Bunların dışında kurumlar veya işletmelerin personel alımlarında tecrübeyi kriter olarak aramalarının yeni mezun bireylerin önündeki engellerden biri olduğu ortaya çıkmıştır. Ayrıca katılımcılar tarafından işe alımlarda torpil, adam kayırma gibi etik ve ahlaki olmayan davranışlar yerine bilgi, beceri, yetenek ve eğitimli olmanın yani liyakat prensiplerinin işe alımlarda tüm kurumlar ve işletmelerce benimsenmesinin işsizlik sorununu önemli ölçüde azaltabileceği görüşü savunulmuştur.

Çalışmada katılımcıların algıladıkları sosyal destek kaynakları ve türlerine verdikleri yanıtlar incelendiğinde; katılımcıların 15 'i \%93.7 oranında anne ve babalarından maddi ve manevi sosyal destek sağladıklarını, 1'i \%6.2 oranında yakın çevre ve arkadaşından sosyal destek sağladığını belirtmiştir. Anne ve baba dışında katılımcılar sosyal destek kaynaklarını; 4 katılımcı (\%25) arkadaş desteği, 3 katılımcı (\%18.7) yakın çevre ve 1 katılımcı (\%6.2) eş olarak ifade etmiştir. Sosyal destek türü ile ilgili olarak ise, 11 katılımc1 \%68.7 oranında hem maddi hem de manevi sosyal destek algıladığını, 4 katılımcı $\% 25$ oranında yalnızca maddi sosyal destek algıladığını, 1 katılımcı ise maddi ve manevi sosyal destek algılamadığını açıklamıştır. Maddi sosyal destek türü, para, harçlık verilmesi, ulaşım, gıda, giyim, faturaların ödenmesi şeklinde katılımcılar tarafından açıklanmıştır. Manevi sosyal destek türü katılımcılar tarafından moral verme, teselli etme, yanında durma, düşünce ve duygu paylaşımı olarak ifade edilmiştir.

\section{Sonuç}

Araştırmada katılımcıların görüşleri doğrultusunda iş yaşamının insanlar için önemi ile ilgili olarak, en fazla psikolojik güç sağladığı bunu var oluş gereksinimi, para kazanmak ve amaçlı yaşamın takip ettiği belirlenmiştir. İş, insanın toplumsal yapıda statü sağlaması, saygın bir birey olması için işlev görmektedir. Sosyal yapıda birey ait olduğu iş veya mesleği ile sosyal kimliğini oluşturmakta, kendisini bu kimlikle tanımlamaktadır. Aynı zamanda idealleri ve istekleri doğrultusunda bireyin iş sahibi olması psikolojik sağlı̆̆ı açısından da önemli bir fonksiyonu yerine getirmektedir. Günümüzde insanların büyük bir kısmı kentlerde, şehirlerde yaşamaktadır, kırsal kesimde ve köylerde yaşayan insanlara göre kentlerde yaşamsal gereksinimlerin karşılanması bir işte çalışmayı ve para kazanmayı gerektirmektedir. Bu nedenle iş karşıllı̆ı elde edilen kazanç kişinin yaşamını devam ettirmesi açısından zorunluluktur. İş ve emek karşılığı kazanılan para temel gereksinimleri karşılamanın dışında yaşam standartlarını belirleyen, sosyal ilişkileri etkileyen bir unsur olabilmektedir. Kişinin gelecekle ilgili planlar 
yapabilmesi, amaçlı bir yaşam içinde olması, ilgi ve yetenekleri ölçüsünde kendisini gerçekleştirmesi, işi ve elde ettiği kazancı doğrultusunda mümkündür. Katılımcıların iş yaşamının insanlar için önemine ilişkin görüşleri sonucunda, bir işe sahip olan kişinin psikolojik olarak güçlü, yaşamsal gereksinimlerini karşılamasının yanında, emek karşılığı maddi kazancının olduğu ve geleceği planlayarak, amaçlı bir yaşam içinde bulunduğu çıkarımı yapılabilir. Günümüz insanı için çalışmak, yalnızca geçim sağlamak amacıyla gerekli parayı kazanmanın ötesinde becerilerimizi kullanma, geliştirme ve topluma hizmet ederek değer üretme anlamı taşımaktadır (İslamoğlu 2010)

İşsizliğin neden olduğu ekonomik sorunlarla ilgili olarak katılımcıların görüşleri doğrultusunda elde edilen sonuçlar incelendiğinde, en fazla yaşamsal gereksinimleri karşılayamamak, bunu aileye yük olmak ve ekonomik bağlılık ile geçim sıkıntısı yaşamak izlemiştir. Yaşamsal gereksinimler, gıda, giyim, barınma, sağlık, temizlik, eğitim, ulaşım, iletişim vb. gibi sayılabilir. İşsiz insanlar bu gereksinimlerini karşılayacak maddi imkanlardan yoksun oldukları için ebeveynlerinden, akrabalarından veya yakın çevrelerindeki insanlardan bu ihtiyaçlarını karşılamak zorunda kalmaktadır. İşsizlerin çalışabilecek fiziksel güç, eğitim, donanım ve psikolojik sağlığa sahip oldukları halde ve çalışmak isteyip, kendilerine uygun bir iş bulamadıklarında aile ve yakın çevrelerinden para alarak gereksinimlerini karşılamaya çalışmaları onlarda diğer insanlara yönelik ekonomik olarak bağlı ve yük oldukları duygularını yaşatabilmektedir. Özellikle evli olan işsizler evin günlük ve aylık giderlerini (gıda, kira, aidat, elektrik, su, doğalgaz, internet ve diğer faturalar) çocukları varsa çocuklarının ihtiyaçlarını karşılamakta güçlük çektiklerinde veya karşılayamadıklarında geçim sıkıntısı yaşayabilmektedir. Katılımcıların işsizliğin yarattığı ekonomik sorunlarla ilişkili görüşleri değerlendirildiğinde; mezuniyet sonrası Kredi Yurtlar Kurumu (KYK) burs ödemeleri için iki yıl süre verilse bile, iki yıl sonra iş bulunmaması halinde de KYK bursunun geri ödenmesi yükümlülüğü bulunmaktadır. Ev geçimi, zorunlu ihtiyaçların karşılanmasının da bu duruma eklenmesiyle çalışacak gücü ve enerjisi olan bu insanlar ailelerine bağımlı hale gelmektedir. Genç işsiz bireyler ailelerinden ekonomik destek alarak ihtiyaçlarını karşılasalar dahi para harcamaları gereken yer ve durumlarda (arkadaşlarıyla bir yere gitmek gibi) rahat davranamamakta çoğu zaman para harcamamak için çeşitli bahanelerle arkadaşlarından, sosyal ortamlardan uzak kalmaktadır. Ayrıca işsizliğin neden olduğu ekonomik sıkıntılar nedeniyle nişan ve evlilik planlarının ertelenmesi de bu bireylerde üzüntüye, strese, hayal kırıklığına ve ebeveynlerinden bağımsız yaşam kuramamalarına, yaşam doyumlarının azalmasına neden olabilmektedir. Yaşamsal ve sosyal gereksinimlerini karş1layamamak insanları etrafındaki yakınlarından beklenti içinde olmaya zorlamaktadır. Tüm bunların işsiz bireyler için kötü bir yaşantı ve duruma sebebiyet verdiği anlaşılmaktadır. Temel ihtiyaçlarını dahi karş1layamayan, ailelerinden veya bankalardan ekonomik yardım almak zorunda kalan genç işsiz bireylerin psikolojik baskı altında olmaları, bankalarla icra problemleri yaşamaları sonucunda olumsuz duygular içinde bulundukları söylenebilir. İşsizlik nedeniyle insanlar sosyal güvenceden yoksun oldukları gibi sağlık hizmetlerinden de yararlanamamaktadır. Bu sonuçlar literatürde yer alan araştırma bulgularıyla da örtüşmektedir (Strandh 2000; Böckerman \& Ilmakunnas 2006; Feldman 2007; Bender \& Theodossiou 2015).

İşsizliğin neden olduğu sosyal sorunlarla ilgili olarak katılımcılardan elde edilen sonuçlar incelendiğinde; en fazla sosyal faaliyetlere katılamamak, bunu toplumsal baskı, arkadaşlardan uzaklaşmak, evlenememek ve boşanma sorunlarının izlediği belirlenmiştir. İnsanın sosyal yönü düşünüldüğünde sosyal gereksinimlerin karşılanması (sosyal, sportif ve kültürel faaliyetlere katılma, konser, tiyatro, sinema, kafe ya da pastaneye gitme, arkadaşlarının doğum günü için kutlama yapma, hediye alma vb. gibi) için para harcanması gerekmektedir. İşsiz bireyler para harcama gerektirdiği için sosyal faaliyetlere katılamamakta, kendilerini sosyal çevreden ve arkadaşlarından izole etmekte veya uzaklaştırmaktadır. İşsiz insanlar arkadaş çevresiyle veya akrabalarla bir araya geldiklerinde konuşma sırasında konu dönüp dolaşıp işsizliğe geldiğinde, 
kendilerini baskı altında hissedebilmektedir. Eğitimli genç işsiz bireyler bir iş sahibi olamadıkları için evlenme planlarını ya ertelemekte ya da ailelerinin maddi desteği ile evlilik yapmak zorunda kalabilmektedir. Evliliği sırasında işsiz olan bireyler ise geçim sıkıntısı yaşadıkları için aile ilişkileri bozulmakta ve boşanmalar söz konusu olabilmektedir. Bu durum işsiz bireylerde isteklerini, ideallerini gerçekleştirememenin verdiği engellenmişlik duygusunu ortaya çıkarabilir. Sosyal ve ekonomik sistemdeki adaletsizliğin yarattığı dezavantajlı konum işsiz bireyde ekonomik ve toplumsal sisteme karşı öfke ve gerginliğe neden olabilir. Dolayısıyla işsizliğin bu yönü bireyde topluma ve toplumun değerlerine yönelik yabancılaşmaya, aidiyet duygusunun azalmasına, yalnızlık duygusuna ve toplumdan dışlanmaya yol açabilir (Sümer et al. 2013). İşsizlik aile içi şiddete ve boşanmaya neden olan toplumsal sorunlara da yol açabilmektedir (Jensen \& Smith 1990; Hansen 2005; Kurt 2006; Özer \& Topal 2017). Bunların dışında işsizlik çeşitli toplumsal sorunlara da yol açabilir söz gelimi insanlar işsizlik nedeniyle suç işlemeye ve ahlaki olmayan eylemlere yönelebilir.

İşsizliğin neden olduğu psikolojik sorunlara ilişkin katılımcıların yanıtlarından elde edilen sonuçlar incelendiğinde; en fazla üzüntü yaşandığı bunu sırasıyla özgüven kaybı, tahammülsüzlük, içe kapanma, stres, depresyon, değersizlik, mutsuzluk, yetersizlik ve uykusuzluk sorunlarının izlediği belirlenmiştir. İşsizliğe gösterilen psikolojik sorunların farklılaşmasında kişilik, yaşam deneyimleri, işsizliğe yönelik kişisel algı ve değerlendirme farklılıkları gibi faktörlerin rolü olabilir. İşsizlik üzerinde yapılan birçok araştırmada işsizliğin stres, depresyon, anksiyete, somatizasyon, hostilite, paranoya gibi psikolojik sorunlara yol açtığı açıklanmıştır (Frese \& Mohr 1987; Jahoda 1988; Kessler et al. 1988; Liem \& Liem 1988; Whelan 1992; Eraslan 2005). Bunlar dışında işsizliğin yaş ile ilişkisinin ele alındığ 1 bir araştırmada 31-55 yaş arasındaki işsizlerin 18-30 yaş arasındaki genç bireylere göre daha stresli ve depresif oldukları bulunmuştur bu bulgunun dişında yapılan diğer araştırmalarda işsizliğin insanlarda artan depresyon, azalan öz saygı, güçsüzlük duyguları ve zayıf sağlıkla ilişkisi olduğu ortaya konmuştur (Dooley et al. 1996; 2000; Breslin \& Mustard 2003). Türk işsizler üzerinde yapılan benzer bir çalışmada da psikolojik sağlı̆ın önemli belirleyicilerinin özsaygı, sosyal destek ve uygun miktarda maddi destek olduğu belirlenmiştir (Bilgiç \& Yılmaz 2013).

Araştırmada işsizliğin neden olduğu sonuçlar, iki alt tema altında toplanmıştır. Bunlar bireysel sonuçlar; mutsuz hayat, düşük maaş ile çalışmak zorunda olmak, psikolojik sorunlar, hayat kuramamak, evlenememek gibi bireysel düzeyde öne çıkan problemler iken, Toplumsal sonuçlar; beyin göçü, ülke kalkınmasının olumsuz etkilenmesi, boşanma, ahlaki ve sosyal sorunlar olarak ortaya çıkmıştır. Bireysel olarak işsiz insanlar isteklerini yapamamanın getirdiği engellenmişlik duygusu içinde bulunabilirler. Zaman zaman iş bulsa da insanlar işverenlerin daha düşük maaş önerileriyle karşılaşabilmektedir. İşsizliğin getirdiği olumsuzluklar psikolojik sorunların yaşanmasını tetikleyebilir, alkol, sigara, uyuşturucu bağımlılığı ve işsizlik nedeniyle tüm bu olumsuzluklar bir araya geldiğinde insanlar geleceklerini planlamada, hayat kurmakta, evlenmekte, yaşamını sürdürmekte sorunlar yaşayabilirler. İşsizliğin toplumsal sonuçlarından olan beyin göçü genç ve eğitimli dinamik insan kaynağının başka ülkelere gitmesi ile göç veren ülkenin ekonomik kayıp yaşaması anlamına gelmektedir. Bu da yetişmiş insanını göç veren bir ülke için ekonomik ve sosyal kalkınmanın sekteye uğraması demektir (Pazarcık 2010). Toplumsal yapının en küçük birimi olan ailenin işsizlik nedeniyle dağılması, toplumu olumsuz olarak etkileyebilir. Ayrıca işsizlik nedeniyle geliri olmayan insanlar illegal davranışlara (uyuşturucu ticareti, fuhuş, hırsızlık, gasp vb.) yönelebilirler.

İşsizlik sorununun çözümlenmesine yönelik katılımcıların görüşleri incelendiğinde; Eğitim stratejisi oluşturulması, işe alımlarda adil tutum ve istihdam politikası oluşturulması ile ilgili sonuçlara ulaşılmıştır. Katılımcıların eğitim stratejisi oluşturulması kategorisinde, çok sayıda üniversiteden mezun verildiği, iş bulma olasıllğı çok az olan bölümlere halen öğrenci alımlarının yapıldığı, bunun işsizliği artırmaktan başka bir şeye yaramadığı açıklanmıştır. Bu yöndeki 
eğitim stratejisi yerine iş bulma olanağı az olan üniversitelerdeki bölümlerin kapatılması, istihdam alanı olan bölümlere nitelikli ögrencilerin alınması, üniversiteye az ama başarılı bireylerin alınmasının gerekliliği ifade edilmiştir. Ayrıca şuan ki eğitim stratejisinin tüm bireyleri yükseköğretime yönlendirdiği bir eğitim politikası yerine, ilkokuldan başlayarak kişilik, mesleki ilgi, istek ve yetenek durumuna göre bireylere eğitim süreci içinde titiz ve sistemli mesleki rehberlik çalışmaları yapılabilir (Ekin 1980). Türkiye'deki genç işsizliğin yüksek olmasının en önemli sebeplerinden biri Türk eğitim sisteminin piyasa-emek talebine cevap verebilecek nitelikte olmamasıdır (Bayraktar \& İncekara 2013). Bir başka ifadeyle Türk eğitim sistemi küçük ve orta ölçekli işletmelerin ihtiyaç duyduğu ara elemanları yetiştirecek eğitim ve öğretim politikası üretmemektedir ayrıca mesleki okullara gereken önem ve destek de verilmemektedir. Planlı istihdam politikası ile Devlet Planlama Teşkilatı Türkiye'nin gelecek 10, 20, 30 ve 50 yıl sonrası hangi iş alanlarında hangi meslek elemanlarına ihtiyacı olacağı ile ilgili çalışmalar yapabilir, ihtiyaç duyulacak iş alanlarına bireylerin mesleki eğitimden geçirilerek yönlendirilmesi sağlanabilir. Böyle bir istihdam politikası nüfusu genç olan bir ülkenin dinamik insan kaynağını en rasyonel bir şekilde kullanmasına imkan vereceği gibi beyin göçünü ve işsizlik sorununu da önemli ölçüde azaltabilir. Bunun dışında kamu yatırımlarının yeni iş alanları ve istihdam olanakları yaratabilmesi için özel sektör üretimini teşvik edecek doğrultuda olması da gerekmektedir. İşe alımlarda adil tutum alt teması doğrultusunda katılımcıların öne çıkan görüşleri; işverenlerin işe alımlarda deneyimi aranan koşul olarak istemeleri ve işe alımlarda kayırmacılık yapılmasıdır. Eğitimlerini tamamlayan yeni mezun insanların iş aramaya başladıklarında işverenlerin 2 yıl, 3 yıl iş deneyimi talepleri ile karşılaşmaları onlarda hayal kırıklığı ya da adil olmayan bir tutumla karşı karşıya kaldıkları duygusuna yol açmaktadır. İşverenlerin bu yöndeki talepleri iş piyasasındaki rekabet koşulları nedeniyle haklı gibi görünse de bu talep işe yeni başlayacak çalışanlara işlerinde gelişmeleri için firsat vermemektedir. İşe alımlarda adil tutumla ilgili olarak katılımcılar tarafından öne sürülen bir diğer görüş, işe alımlarda çok fazla kayırmacılık ve torpil yapılmasıdır. Kayırmacılık ve nepotizm Türkiye'de de farklı iş alanlarında sıklıkla karşılaşılan ve yaygın olan olgular olup, işe alım veya terfi sürecinde akrabaların, tanıdıkların tercih edildiği, onlara ayrıcalık tanındığı iş yaşamında etik dışı ve adil olmayan bir davranış biçimidir (Çivilidağ \& Şekercioğlu 2016). Kayırmacılık, örgütsel adaleti, motivasyonu ve çalışanlar arası uyumu bozan bir etkiye sahiptir. Kayırmacılığın olduğu örgütlerde çalışanlar arasında güvensizlik ve çatışma ortaya çıkabilir, çalışanlar işten ayrılmayı düşünebilir veya çalışanların meslektaşları, müşterilerle örgütteki kayırmacılığı konuşmaları örgüte zarar verebilir (Özler \& Büyükarslan 2011). Kamu veya özel kurumlarda işe alımlar liyakat ilkesine göre yapılmalı ve işe alım süreci açık bir şekilde ilan edilmelidir. Kayırmacılığın önlenmesi için Çalışma Bakanlığı ve sendikalar tarafından çalışmalar yapılabilir, kurumlar denetlenebilir ve yaptırımlar uygulanabilir.

İşsizlik sorunu ile başa çıkmada kişinin çevresinden aldığı sosyal destek önemli bir işlev görmektedir. Araştırmada işsiz bireylerin büyük oranda ebeveynlerinden maddi ve manevi sosyal destek aldıkları bunu yakın çevre ve arkadaşların izlediği belirlenmiştir. İşsizlik stresli, kaygılı bir durumdur ve stres karşısında insanların çevrelerindeki insanlardan destek görmeleri onların yıpratıcı koşullara dayanma güçlerini artırabilir. Aile önemli bir sosyal destek kaynăğdır. Türkiye'de ebeveynler, çocuklarının yükseköğrenim sonrasında işe girene kadar hatta işe girse de eğer birey evli değilse sosyal destek sağlamaktadır. Evlenerek ailesinden ayrılan kişiler için eşlerden sağlanan sosyal destek de ayrıca dikkate alınmalıdır. Avrupa ülkelerinde işsizlik ve sosyal dışlanma ile ilgili yapılan bir incelemede özellikle genç işsizler için en önemli koruyucu faktörün sosyal destek olduğu belirtilmiştir. Kuzey Avrupa ülkelerinde işsiz genç bireylerin sosyal ağlara bağlanması sosyal destek açısından büyük öneme sahipken, güney Avrupa ülkeleri için aile desteğinin daha önemli olduğu belirlenmiştir (Kieselbach 2003). Yapılan bir başka araştırmada medeni durumu evli olan insanların işsizliğin ortaya çıkardığı stresli koşullara 
dayanmalarında evliliğin önemli etkisinin olduğu, evliliğin stresli işsizlik koşulları için tampon bir rol oynayarak sosyal destek sağladığı belirlenmiştir (Dooley et al. 2000). Güçlü sosyal desteğin insanların psikolojik ve fizyolojik sağlıkları üzerinde yararlı etkileri olduğu belirlenmiştir (Roberts et al. 1997). İşsizlik sorunu ile başa çıkmada bireysel stratejiler de geliştirilebilir. Bireyler günlük yaşamlarını çalışıyormuş gibi düzenleyebilirler, uyku ve yemek yeme davranışlarını çalıştıkları zamanki gibi düzenli devam ettirebilirler. İş arama sürecinde hobileriyle ilgilenebilirler veya çalıştıkları süre içinde yapamadıkları aktiviteleri gerçekleştirebilirler. Bu süre içinde işsiz bireyler kısa erimli ve uzun erimli amaçlar belirleyerek bunları başarmak için çaba sarf edebilirler, böylelikle işsizliğin neden olduğu strese karşı psikolojik yapılarını güçlendirebilirler (Aytaç \& Keser 2002).

$\mathrm{Bu}$ araştırma üniversite mezunu, genç 16 işsiz katılımcının araştırmada incelenen sorulara verdikleri yanıtlarla sınırlıdır. Nitel araştırmalarda genelleyici sonuçlara ulaşmaktan ziyade var olan olgu veya sorunu derinlemesine ele alıp açıklamak, betimlemek, incelemek amaçlanır. $\mathrm{Bu}$ çalışma da bu doğrultuda Türkiye'de gündemin üst sıralarında yer alan işsizlik olgusunu, işsiz bireyler üzerinde incelemek ve açıklamak amacıyla yapılmıştır. Gelecekte yapılacak araştırmalarda farklı yöntemler kullanılarak, işsizlik olgusu farklı değişkenlerle incelenebilir. İşsizliğe etkisi olduğu düşünülen (eğitim sistemi, kayırmacılık, istihdam politikası, ekonomi politikası, mülteciler gibi) ilişkili faktörler incelenebilir. Daha büyük örneklem gruplarıyla nicel çalışmalar yapılarak genelleyici sonuçlara ulaşılabilir veya hem nitel hem de nicel yöntemin birlikte kullanıldığı karma desenli araştırmalar yapılarak, işsizlik sorunuyla ilgili kapsamlı sonuçlar ortaya konulabilir.

\section{Yazarın Notu:}

Bu çalışma 4-6 Ekim 2019 Tarihleri arasında Ankara Uluslararası Bilimsel Araştırmalar Kongresinde yazar tarafindan sözlü bildiri olarak sunulmuş olup, özeti kongre kitapçığında basılmıştır. Bu araştırmanın yapılmasına katkıda bulunan Akdeniz Üniversitesi psikoloji bölümü lisans öğrencileri Ahsen Özge Kurt, Aylin Kaval ve Melike Ülker’e teşekkür ederim. 


\section{KAYNAKÇA}

Aytaç S. \& Keser A. (2002). “İşsizliğin Çalışan Birey Üzerindeki Etkisi: İşsizlik Kaygısı”. İş, Güç Endüstri İlişkileri ve Insan Kaynaklart Dergisi 4/2 (2002). Kaynak: http://www.isguc.org/?p=article\&id= $48 \&$ cilt $=4 \&$ sayi $=2 \&$ yil $=2002$

Bayraktar S. \& İncekara A. (2013). Türkiye’nin Genç İşsizlik Profili. Çalışma İlişkileri Dergisi 4/1 (2013) 15-38.

Bender K. A. \& Theodossiou I. (2015). "A Reappraisal Of The Unemployment-Mortality Relationship: Transitory and Permanent Effects”. Journal of Public Health Policy 36 (2015) 81-94. doi: i0.i057/jph

Bilgiç R. \& Yılmaz N. (2013). "The Correlates of Psychological Health Among the Turkish Unemployed: Psychological Burden of Financial Help During Unemployment”. International Journal of Psychology 48/5. (2013) 1000-1008.

Breslin F. C. \& Mustard C. (2003). "Factors Influencing the Impact of Unemployment on Mental Health Among Young and Older Adults in a Longitudinal, Population-Based Survey”. Scandinavian Journal of Work, Environment \& Health 29/1 (2003) 5-14.

Böckerman P. \& Ilmakunnas P. (2006). "Elusive Effects of Unemployment on Happiness”. Social Indicators Research 79/1 (2006) 159-169. doi: 10.1007/s 11205-005-4609-5

Çivilidağ A. (2018). Endüstri ve Örgüt Psikolojisi Perspektifinden Insan. Ankara 2018.

Çivilidağ A. \& Şekercioğlu G. (2016). "İşe Personel Alma, Nepotizm ve Örgütsel Gelişme Hakkında İnsan Kaynakları Çalışanlarının Görüşlerine İlişkin Nitel Bir Analiz”. 4. Örgütsel Davranış Kongresi (2016) 619-625. Kaynak: https://docplayer.biz.tr/47658764-Iv-orgutsel-davranis-kongresi-4-5-kasim-2016.html

Dooley D., Jonathan F. \& Lennart L. (1996). “Health and Unemployment”. Annual Review of Public Health 17 (1996) 449-65.

Dooley D., Prause J. \& Ham-Rowbottom K. A. (2000). “Underemployment And Depression: Longitudinal Relationships”. Journal of Health and Social Behavior 41/4 (2000) 421-436.

Ekin N. (1980). "Gençlerin İşsizlik Sorunu”. Sosyoloji Konferansları 18 (1980) 39-50. Kaynak: https://dergipark.org.tr/en/download/article-file/101180

Eraslan L. (2005). "Kamu Personeli Seçme Sınavına Hazırlanan Öğretmen Adaylarının Psiko-Sosyal Durumlarının Betimlenmesi”. Öğretmen Dünyası 12 (2005) 19-21.

Feldman H. (2007). “Economic Freedom and Unemployment Around the World”. Southern Economic Journal 74/1 (2007) 158-176

Frese M. \& Mohr G. (1987). "Prolonged Unemployment and Depression in Older Workers: A Longitudinal Study of Intervening Variables”. Social Science \& Medicine 25/2 (1987) 173-178.

Ganley R. (2002). “The Psychological Impact of Joblessness”. Australian Social Policy 3 (2002) 179-200.

Halvorsen K. (1998). "Impact of Re-Employment on Psychological Distress Among Long-Term Unemployed”. Acta sociologica 41/2/3 (1998) 227-242.

Hansen H. T. (2005). “Unemployment And Marital Dissolution: A Panel Data Study of Norway”. European Sociological Review 21/2 (2005) 135-148.

ILO. (2019). World Employment Social Outlook Trends. 2019. Kaynak: https://www.ilo.org/ wcmsp5/groups/public/---dgreports/---dcomm/---publ/documents/publication/wcms_670542.pdf

İslamoğlu G. (2010). Kurumlarda İyilik Var. Ankara 2010.

Jahoda M. (1988). “Economic Recession And Mental Health: Some Conceptual Issues”. Journal of Social Issues 44/4 (1988) 13-23.

Jensen P. \& Smith N. (1990). “Unemployment and Marital Dissolution”. Journal of Population Economics 3/3 (1990) 215-229.

Kessler R. C., Tumer J. B. \& House J. S. (1988). "Effects of Unemploy- Ment on Health in a Community Survey: Main, Modifying, and Mediating Effects”. Journal of Social Issues 44/4 (1988) 69-85.

Kieselbach T. (2003). "Long Term Unemployment Among Young People: The Risk of Social Exclusion”. American Journal of Community Psychology 32/1/2 (2003) 69-76.

Kroll L. E. \& Lampert T. (2011). "Unemployment, Social Support and Health Problems: Results of the Geda Study in Germany, 2009”. Deutsches Ärzteblatt International 108/4 (2011) 47-52.

Kurt Ş. (2006). "İşsizliğin Psiko-Sosyal Sonuçları ve Türkiye Üzerine Muhtemel Etkileri”. Sosyal Siyaset Konferanslart Dergisi 51 (2006) 357-379.

Liem R. \& Liem J. H. (1988). "Psychological Effects of Unemployment on Workers and Their Families”. 
Journal of Social Issues 44/4 (1988) 87-105.

Merriam S. B. (2013). Nitel Araştırma Desen ve Uygulama İçin Bir Rehber. Ankara 2013.

Özer U. \& Topal M. H. (2017). “Genç İşsizliği, Suç, Göç, İntihar ve Boşanma Düzeyleri ile İlişkili Midir? Türkiye'den Ampirik Bir Kanıt”. Kırklareli Üniversitesi İktisadi ve İdari Bilimler Fakültesi Dergisi 6/5 (2017) 50-63.

Özler N. D. E. \& Büyükarslan B. A. (2011). “The Overall Outlook of Favoritism in Organizations: A Literature Review”. International Journal of Business and Management Studies 3/1 (2011) 275-285.

Pazarcık S. F. (2010). Beyin Göçü Olgusu ve Amerika Birleşik Devletleri Üniversitelerinde Çalışan Türk Sosyal Bilimciler Üzerine Bir Araştırma. Yayımlanmamış Yüksek Lisans Tezi. Çanakkale Onsekiz Mart Üniversitesi Sosyal Bilimler Enstitüsü 2010.

Preti A. (2003). “Unemployment and Suicide”. J Epidemiol Community Health 57 (2003) 557-558.

Roberts H., Pearson J. C. G., Madeley R. J., Hanford S. \& Magowan R. (1997). "Unemployment and Health: The Quality of Social Support Among Residents in the Trent Region of England”. Journal of Epidemiology and Community Health 51 (1997) 41-45.

Sandalcılar A. R. (2012). “İşsizlik Boşanmayı Etkiliyor Mu? Bölgesel Panel Nedensellik”. Ege Akademik Bakış 2/12 (2012) 225-238.

Stack S. \& Haas A. (1984). "The Effect of Unemployment Duration on National Suicide Rates: A Time Series Analysis, 1948-1982”. Sociological Focus 17/1 (1984) 17-29.

Strandh M. (2000). "Different Exit Routes From Unemployment and Their Impact on Mental Well-Being: The Role of the Economic Situation and the Predictability of the Life Course”. Work, Employment \& Society 14/3 (2000) 459-479.

Sümer N., Solak N. \& Harma M. (2013). İşsiz Yaşam İşsizliğin ve Iş̧ Güvencesizliğinin Birey ve Aile Üzerindeki Etkileri. İstanbul 2013.

TÜİK (2019). Isşücü İstatistikleri Mart 2019. Kaynak: http://tuik.gov.tr/HbGetirHTML.do?id=30683

Whelan C. T. (1992). "The Role of Income, Life Style Deprivation and Financial Strain in Mediating the Impact of Unemployment on Psychological Distress: Evidence from the Republic of Ireland”. Journal of Occupational and Organizational Psychology 65/4 (1992) 331-344.

Yıldırım A. \& Şimşek H. (2013). Sosyal Bilimlerde Nitel Araştırma Yöntemleri. Ankara 2013. 
